\title{
Zosteropenillines: Polyketides from the Marine-Derived Fungus Penicillium thomii
}

\author{
Shamil Sh. Afiyatullov ${ }^{1, *,+}{ }^{\dagger}$ Elena V. Leshchenko ${ }^{1,2, *, \dagger}$, Dmitrii V. Berdyshev ${ }^{1}$, \\ Maria P. Sobolevskaya ${ }^{1}$, Alexandr S. Antonov ${ }^{1}$, Vladimir A. Denisenko ${ }^{1}$, Roman S. Popov ${ }^{1}$, \\ Mikhail V. Pivkin ${ }^{1}$, Anatoly A. Udovenko ${ }^{3}$, Evgeny A. Pislyagin ${ }^{1}$, Gunhild von Amsberg ${ }^{4}$ and \\ Sergey A. Dyshlovoy ${ }^{1,2,4}$ \\ 1 G.B. Elyakov Pacific Institute of Bioorganic Chemistry, Far Eastern Branch of Russian Academy of Sciences, \\ 159 Prospect 100-letiya Vladivostoka, Vladivostok 690022, Russia; berdyshev@piboc.dvo.ru (D.V.B.); \\ sobolevskaya_m@mail.ru (M.P.S.); alexanderantonovpiboc@gmail.com (A.S.A.); \\ vladenis@piboc.dvo.ru (V.A.D.); prs_90@mail.ru (R.S.P.); pivkin@piboc.dvo.ru (M.V.P.); \\ pislyagin@hotmail.com (E.A.P.); dyshlovoy@gmail.com (S.A.D.) \\ 2 School of Natural Science, Far Eastern Federal University, 8 Sukhanova St., Vladivostok 690090, Russia \\ 3 Institute of Chemistry, Far Eastern Branch of Russian Academy of Sciences, \\ 159 Prospect 100-letiya Vladivostoka, Vladivostok 690022, Russia; udovenko@ich.dvo.ru \\ 4 Laboratory of Experimental Oncology, Department of Oncology, Hematology and Bone Marrow \\ Transplantation with Section Pneumology, Hubertus Wald-Tumorzentrum, University Medical Center, \\ 20246 Hamburg, Germany; g.von-amsberg@uke.de \\ * Correspondence: afiyat@piboc.dvo.ru (S.S.A.); bykadorovachem@gmail.com (E.V.L.); \\ Tel.: +7-423-231-1168 (S.S.A.); +7-432-231-1430 (E.V.L.) \\ + These authors contributed equally to this work.
}

Academic Editor: Russell Kerr

Received: 28 December 2016; Accepted: 13 February 2017; Published: 17 February 2017

\begin{abstract}
Twelve new polyketides, zosteropenillines A-L (1-12), together with known polyketide pallidopenilline A (13), were isolated from the ethylacetate extract of the fungus Penicillium thomii associated with the seagrass Zostera marina. Their structures were established based on spectroscopic methods. The absolute configuration of zosteropenilline A (1) as $4 R, 5 S, 8 S, 9 R, 10 R$, and $13 S$ was determined by a combination of the modified Mosher's method, X-ray analysis, and NOESY data. Absolute configurations of zosteropenillines B-D (2-4) were determined by time-dependent density functional theory (TD-DFT) calculations of ECD spectra. The effect of compounds 1-3, 7, 8, 10, and 11 on the viability of human drug-resistant prostate cancer cells PC 3 as well as on autophagy in these cancer cells and inhibitory effects of compounds $\mathbf{1}, \mathbf{2}$, and $\mathbf{8 - 1 0}$ on NO production in LPS-induced RAW 264.7 murine macrophages were examined.
\end{abstract}

Keywords: marine fungi; Penicillium thomii; polyketide decalin derivative; X-ray; ECD spectra

\section{Introduction}

Marine-derived fungi are a prolific source of new secondary metabolites, many of which are biologically active [1-3]. In previously published works, we described the isolation and identification of 10 new meroterpenoids-austalides and seven new 6,6-spiroketals-sargassopenillines A-G from fungi Penicillium thomii and P. lividum associated with the brown alga Sargassum miyabei $[4,5]$ and four new eudesmane-type sesquiterpenes-thomimarines A-D from P. thomii KMM 4667 associated with the sea grass Zostera marina [6]. Recently, we have isolated 11 new polyketides, pallidopenillines that have a polyketidic decalin scaffold from $P$. thomii associated with the brown alga Sargassum pallidum [7]. During our ongoing search for new natural compounds from marine-derived fungi, we investigated the strain P. thomii KMM 4674 isolated from the seagrass Z. marina. Herein, we report the isolation, 
structure elucidation and biological assay results of 12 new polyketides containing "decalin" motif produced by this fungus (Figure 1).

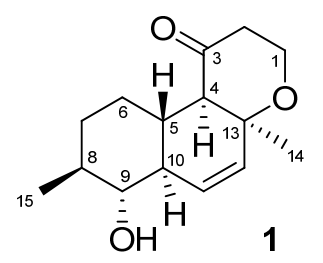<smiles>CC1CC[C@]2(C)C(C=C[C@]3(C)OCCC(=O)C32)C1</smiles>

4<smiles>CC1CCC2(C)C(C=C[C@](C)(O)C2C(=O)CCO)C1</smiles>

7<smiles>C[C@]1(O)C=CC2CC(CO)CCC2C1C(=O)CCO</smiles><smiles>C[C@]12C=C[C@H]3C[C@@H](CO)CC[C@H]3[C@H]1C(=O)CCO2</smiles>

2

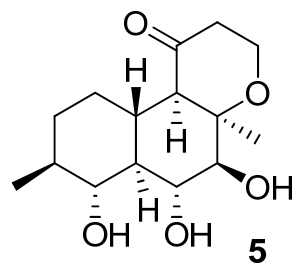<smiles>CC1=CC[C@H](O)[C@H]2C(C(=O)CCO)CC[C@H](C)[C@@H]12</smiles>

8<smiles>C[C@]1(O)C(=O)C=C2CC(CO)CC[C@H]2C1C(=O)CCO</smiles><smiles>C[C@]1(O)CC[C@H]2C(C=C[C@]3(C)OCCC(=O)[C@H]23)C1</smiles><smiles>CC1CCC2(C(C)C=C[C@H](O)C2C(=O)CCO)[C@H](O)C1C</smiles>

6<smiles>C=C1C=C[C@H]2C(C(=O)CCO)CC[C@]2(C)C1C</smiles>

$\mathrm{HO}$<smiles>C[C@]1(O)C(C(=O)CCO)[C@H]2CCC(CO)CC2=C[C@H]1O</smiles>

12

Figure 1. Structures of zosteropenillines A-L (1-12).

\section{Results and Discussion}

\subsection{Structure Elucidation}

The molecular formula of 1 was established to be $\mathrm{C}_{15} \mathrm{H}_{22} \mathrm{O}_{3}$ from a HRESIMS peak at $m / z 273.1461$ $[\mathrm{M}+\mathrm{Na}]^{+}$and by ${ }^{13} \mathrm{C}$ NMR analyses. A close inspection of ${ }^{1} \mathrm{H}$ NMR, ${ }^{13} \mathrm{C}$ NMR, DEPT, and HSQC data of 1 (Tables 1 and 2) revealed the presence of two methyl $\left(\delta_{\mathrm{H}} 1.26, \delta_{\mathrm{C}} 23.2\right.$ and $\left.\delta_{\mathrm{H}} 1.03, \delta_{\mathrm{C}} 18.4\right)$ groups, four methylenes $\left(\delta_{C} 39.9,32.7,28.7\right)$, including one oxygen-bearing $\left(\delta_{H} 4.11,3.89, \delta_{C} 60.9\right)$, and seven methines $\left(\delta_{\mathrm{H}} 1.89, \delta_{\mathrm{C}} 37.5, \delta_{\mathrm{H}} 1.41, \delta_{\mathrm{C}} 40.2, \delta_{\mathrm{H}} 1.65, \delta_{\mathrm{C}} 48.6, \delta_{\mathrm{H}} 2.09, \delta_{\mathrm{C}} 62.8, \delta_{\mathrm{H}} 6.24, \delta_{\mathrm{C}} 130.1, \delta_{\mathrm{H}} 5.69\right.$, $\left.\delta_{C} 131.6\right)$, together with one oxygen-bearing $\left(\delta_{H} 2.92, \delta_{C} 77.9\right)$, one carbonyl carbon $\left(\delta_{C} 210.2\right)$, and one oxygenated quaternary carbon $\left(\delta_{C} 74.7\right)$. These data and five unsaturated degrees from the molecular formula suggested that compound 1 possessed three rings. COSY-45 data and HMBC correlations (Figure 2$)$ from $\mathrm{H}-4\left(\delta_{\mathrm{H}} 2.09\right)$ to $\mathrm{C}-5\left(\delta_{\mathrm{C}} 37.5\right), \mathrm{C}-10\left(\delta_{\mathrm{C}} 48.6\right), \mathrm{C}-14\left(\delta_{\mathrm{C}} 23.2\right)$, from H-5 $\left(\delta_{\mathrm{H}} 1.89\right)$ to $\mathrm{C}-4$ $\left(\delta_{C} 62.8\right), C-6\left(\delta_{C} 28.7\right), C-10, C-13\left(\delta_{C} 74.7\right)$, from $H_{2}-6\left(\delta_{H} 1.28,1.14\right)$ to $C-5, C-7\left(\delta_{C} 32.7\right), C-8\left(\delta_{C} 40.2\right)$ and C-10, from H-7a $\left(\delta_{\mathrm{H}} 1.78\right)$ to $\mathrm{C}-5, \mathrm{C}-6, \mathrm{C}-8$ and $\mathrm{C}-15\left(\delta_{\mathrm{C}} 18.4\right)$, from $\mathrm{H}-7 \mathrm{~b}\left(\delta_{\mathrm{H}} 1.08\right)$ to $\mathrm{C}-9\left(\delta_{\mathrm{C}} 77.9\right)$, from $\mathrm{H}-8\left(\delta_{\mathrm{H}} 1.41\right)$ to $\mathrm{C}-7, \mathrm{C}-9$ and C-10, from $\mathrm{H}_{3}-15\left(\delta_{\mathrm{H}} 1.03\right)$ to C-7, C-8 and C-9, from H-9 $\left(\delta_{\mathrm{H}} 2.92\right)$ to $\mathrm{C}-10, \mathrm{C}-11\left(\delta_{\mathrm{C}} 130.1\right), \mathrm{C}-15$, from $\mathrm{H}-10\left(\delta_{\mathrm{H}} 1.65\right)$ to $\mathrm{C}-11, \mathrm{C}-12\left(\delta_{\mathrm{C}} 131.6\right)$, from $\mathrm{H}-11\left(\delta_{\mathrm{H}} 6.24\right)$ to $\mathrm{C}-13$, from $\mathrm{H}-12\left(\delta_{\mathrm{H}} 5.69\right)$ to $\mathrm{C}-4, \mathrm{C}-13$, and C-14 revealed the presence of a decalin moiety and established a $\Delta^{11}$ double bond and the location of methyl groups at C-8 and C-13 in $\mathbf{1}$. 
Table 1. ${ }^{13} \mathrm{C}$ NMR spectroscopic data ( $\delta$ in ppm) for zosteropenillines A-F (1-6).

\begin{tabular}{|c|c|c|c|c|c|c|}
\hline Position & $1 *$ & $2 *$ & $3 *$ & $4 * *$ & $5 * *$ & $6 *$ \\
\hline 1 & $60.9, \mathrm{CH}_{2}$ & $60.9, \mathrm{CH}_{2}$ & $60.9, \mathrm{CH}_{2}$ & $60.9, \mathrm{CH}_{2}$ & $60.9, \mathrm{CH}_{2}$ & $57.6, \mathrm{CH}_{2}$ \\
\hline 2 & $39.9, \mathrm{CH}_{2}$ & $39.9, \mathrm{CH}_{2}$ & $39.9, \mathrm{CH}_{2}$ & $39.9, \mathrm{CH}_{2}$ & $37.9, \mathrm{CH}_{2}$ & $48.6, \mathrm{CH}_{2}$ \\
\hline 3 & $210.2, \mathrm{C}$ & $210.4, \mathrm{C}$ & $210.3, \mathrm{C}$ & $210.9, \mathrm{C}$ & 206.0, C & $217.6, \mathrm{C}$ \\
\hline 4 & $62.8, \mathrm{CH}$ & $62.9, \mathrm{CH}$ & $62.7, \mathrm{CH}$ & $63.0, \mathrm{CH}$ & $63.7, \mathrm{CH}$ & $61.8, \mathrm{CH}$ \\
\hline 5 & $37.5, \mathrm{CH}$ & $39.5, \mathrm{CH}$ & $38.9, \mathrm{CH}$ & 39.3. $\mathrm{CH}$ & $38.5, \mathrm{CH}$ & $37.4, \mathrm{CH}$ \\
\hline 6 & $28.7, \mathrm{CH}_{2}$ & $28.8, \mathrm{CH}_{2}$ & $38.7, \mathrm{CH}_{2}$ & $29.3, \mathrm{CH}_{2}$ & $29.0, \mathrm{CH}_{2}$ & $29.4, \mathrm{CH}_{2}$ \\
\hline 7 & $32.7, \mathrm{CH}_{2}$ & $29.1, \mathrm{CH}_{2}$ & $24.9, \mathrm{CH}_{2}$ & $34.9, \mathrm{CH}_{2}$ & $31.8, \mathrm{CH}_{2}$ & $32.9, \mathrm{CH}_{2}$ \\
\hline 8 & $40.2, \mathrm{CH}$ & $40.5, \mathrm{CH}$ & $69.7, \mathrm{C}$ & $32.8, \mathrm{CH}$ & $39.2, \mathrm{CH}$ & $40.6, \mathrm{CH}$ \\
\hline 9 & $77.9, \mathrm{CH}$ & $35.2, \mathrm{CH}_{2}$ & $44.5, \mathrm{CH}_{2}$ & $40.9, \mathrm{CH}_{2}$ & $79.2, \mathrm{CH}$ & $77.8, \mathrm{CH}$ \\
\hline 10 & $48.6, \mathrm{CH}$ & $41.4, \mathrm{CH}$ & $36.9, \mathrm{CH}$ & $41.9, \mathrm{CH}$ & $53.5, \mathrm{CH}$ & $49.1, \mathrm{CH}$ \\
\hline 11 & $130.1, \mathrm{CH}$ & 134.4, $\mathrm{CH}$ & 134.4, $\mathrm{CH}$ & $130.5, \mathrm{CH}$ & $67.3, \mathrm{CH}$ & $128.6, \mathrm{CH}$ \\
\hline 12 & 131.6, $\mathrm{CH}$ & $130.9, \mathrm{CH}$ & 131.1, CH & $134.8, \mathrm{CH}$ & 72.7, CH & 133.0, CH \\
\hline 13 & 74.7, C & 75.0, C & 75.0, C & $75.2, \mathrm{C}$ & $77.5, \mathrm{C}$ & $69.1, \mathrm{C}$ \\
\hline 14 & $23.2, \mathrm{CH}_{3}$ & 23.3, $\mathrm{CH}_{3}$ & 23.3, $\mathrm{CH}_{3}$ & 23.3, $\mathrm{CH}_{3}$ & $22.0, \mathrm{CH}_{3}$ & $28.8, \mathrm{CH}_{3}$ \\
\hline 15 & $18.4, \mathrm{CH}_{3}$ & $68.1, \mathrm{CH}_{2}$ & $31.5, \mathrm{CH}_{3}$ & $22.3, \mathrm{CH}_{3}$ & $19.1, \mathrm{CH}_{3}$ & $18.4, \mathrm{CH}_{3}$ \\
\hline
\end{tabular}

* $\bar{C}_{\text {Chemical shifts were measured at } 125.77 \mathrm{MHz} \text { in } \mathrm{CDCl}_{3} ;{ }^{* *} \text { Chemical shifts were measured at } 176.04 \mathrm{MHz} \text { in } \mathrm{CDCl}_{3}}$.

HMBC correlations from $\mathrm{H}-1 \mathrm{a}\left(\delta_{\mathrm{H}} 4.11\right)$ to $\mathrm{C}-2\left(\delta_{\mathrm{C}} 39.9\right), \mathrm{C}-3\left(\delta_{\mathrm{C}} 210.2\right)$ and $\mathrm{C}-13$, from H-2a $\left(\delta_{\mathrm{H}} 2.64\right)$ to $\mathrm{C}-1\left(\delta_{\mathrm{C}} 60.9\right), \mathrm{C}-3$, from $\mathrm{H}-2 \mathrm{~b}\left(\delta_{\mathrm{H}} 2.21\right)$ to $\mathrm{C}-3, \mathrm{C}-4$ established a saturated $\gamma$-pyrone derivative moiety in 1. NOESY cross-peaks $\mathrm{H}_{3}-14\left(\delta_{\mathrm{H}} 1.26\right) / \mathrm{H}-4\left(\delta_{\mathrm{H}} 2.09\right), \mathrm{H}-1 \beta\left(\delta_{\mathrm{H}} 3.89\right) ; \mathrm{H}_{3}-15$ $\left(\delta_{\mathrm{H}} 1.03\right) / \mathrm{H}-9\left(\delta_{\mathrm{H}} 2.92\right) ; \mathrm{H}-5 / \mathrm{H}-2 \beta\left(\delta_{\mathrm{H}} 2.64\right), \mathrm{H}-6 \beta\left(\delta_{\mathrm{H}} 1.28\right), \mathrm{H}-7 \beta\left(\delta_{\mathrm{H}} 1.08\right), \mathrm{H}-9 ; \mathrm{H}-10\left(\delta_{\mathrm{H}} 1.65\right) / \mathrm{H}-6 \alpha$ $\left(\delta_{\mathrm{H}} 1.14\right), \mathrm{H}-8\left(\delta_{\mathrm{H}} 1.41\right), \mathrm{H}-4 ; \mathrm{H}-9 / \mathrm{H}_{3}-15, \mathrm{H}-5$ and $\mathrm{H}-4 / \mathrm{H}-6 \alpha, \mathrm{H}-10, \mathrm{H}_{3}-14$ indicated a trans-ring fusion of the $\mathrm{A}$ and $\mathrm{B}$ rings, cis-ring fusion of the $\mathrm{B}$ and $\mathrm{C}$ rings, the $\alpha$-orientation of $\mathrm{H}_{3}-14$ and $9-\mathrm{OH}$, and the $\beta$-orientation of $\mathrm{H}_{3}-15$. The planar structure and relative configuration of $\mathbf{1}$ were unequivocally confirmed by X-ray analysis, which was carried out for a single crystal obtained by recrystallization from acetonitrile-water (Figure 2 and Figure S9).
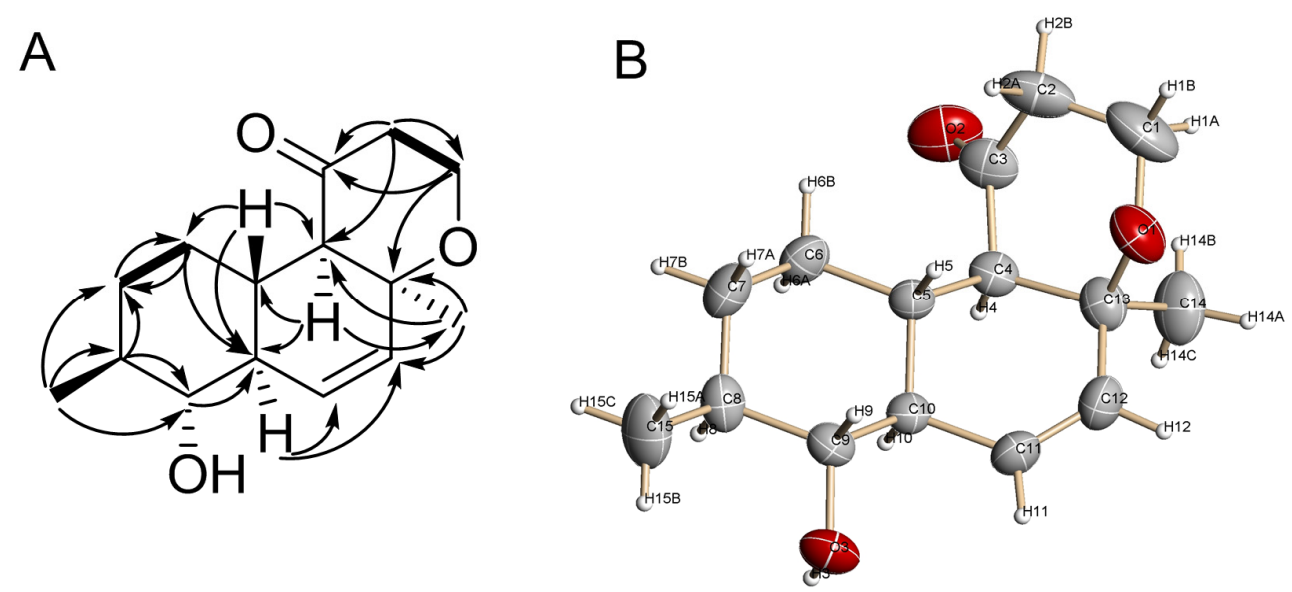

Figure 2. (A) Key HMBC and COSY correlations of 1; (B) Crystal structure of $\mathbf{1}$. 
Table 2. ${ }^{1} \mathrm{H}$ NMR spectroscopic data $(\delta$, $J$ in $\mathrm{Hz}$ ) for zosteropenillines A-F (1-6).

\begin{tabular}{|c|c|c|c|c|c|c|}
\hline Position & $1^{* *}$ & $2 *$ & $3 *$ & $4^{* *}$ & $5^{* *}$ & $6^{*}$ \\
\hline \multirow{2}{*}{1} & a: $4.11, \mathrm{ddd}(12.0,8.0,1.2)$ & a: $4.11, \mathrm{ddd}(11.8,8.0,1.0)$ & a: $4.11, \operatorname{ddd}(11.8,8.0,1.0)$ & a: $4.11, \operatorname{ddd}(11.7,8.0,1.4)$ & a: $4.22, \mathrm{dd}(12.0,9.0)$ & a: 3.91, ddd $(11.7,6.2,4.2)$ \\
\hline & $\mathrm{b}: 3.89, \mathrm{td}(12.0,3.0)$ & $\mathrm{b}: 3.89 \mathrm{td}(12.0,3.0)$ & $\mathrm{b}: 3.89, \mathrm{td}(12.0,2.9)$ & b: $3.89, \operatorname{td}(12.0,3.0)$ & b: $3.91, \operatorname{td}(12.0,4.0)$ & b: 3.87 , ddd $(11.7,6.2,4.2)$ \\
\hline \multirow{2}{*}{2} & a: $2.64, \operatorname{ddd}(14.0,12.0,8.0)$ & a: $2.66, \operatorname{ddd}(14.1,12.1,8.0)$ & a: $2.66, \operatorname{ddd}(14.0,12.1,8.0)$ & a: $2.68, \operatorname{ddd}(14.0,12.0,3.0)$ & a: $2.67, \operatorname{ddd}(15.0,12.0,9.0)$ & a: $2.86, \operatorname{ddd}(18.4,6.2,4.2)$ \\
\hline & b: $2.21, \mathrm{ddt}(14.0,3.0,1.2)$ & b: 2.21 , ddt $(14.1,3.0,1.3)$ & b: 2.21 , ddt $(13.9,2.9,1.3)$ & b: $2.21, \operatorname{ddt}(14.0,3.0,1.5)$ & b: $2.21, \mathrm{dd}(15.0,4.0)$ & b: 2.76 , ddd $(18.4,6.2,4.4)$ \\
\hline 4 & $2.09, \mathrm{dd}(11.8,1.2)$ & $2.07, \mathrm{dd}(11.3,1.2)$ & $2.10, \mathrm{dd}(11.3,1.2)$ & $2.04, \mathrm{dd}(11.5,1.6)$ & $2.11, \mathrm{~d}(11.7)$ & $2.59, \mathrm{~d}(11.4)$ \\
\hline 5 & $1.89, \operatorname{tdd}(11.8,10.6,3.2)$ & $1.78, \mathrm{~m}$ & $1.75, \mathrm{~m}$ & $1.75, \mathrm{~m}$ & $1.95, \mathrm{~m}$ & $1.93, \operatorname{tdd}(11.4,10.4,3.0)$ \\
\hline \multirow{2}{*}{6} & a: $1.28, \mathrm{~m}$ & a: $1.41, \mathrm{dq}(13.2,3.2)$ & a: $1.69, \mathrm{~m}$ & a: $1.34, \mathrm{dq}(13.3,3.6)$ & a: $1.33, \mathrm{~m}$ & a: $1.50, \mathrm{~m}$ \\
\hline & b: 1.14 , qd $(13.0,3.3)$ & b: $1.14, \mathrm{qd}(13.2,3.5)$ & b: $1.41, \mathrm{~m}$ & b: 1.11 , qd $(13.0,3.8)$ & $\mathrm{b}: 1.11, \mathrm{~m}$ & b: $1.15, \mathrm{qd}(12.7,3.2)$ \\
\hline \multirow{2}{*}{7} & a: $1.78, \mathrm{dq}(12.7,3.3)$ & a: $1.85, \mathrm{dq}(12.9,3.4)$ & a: $1.45, \mathrm{~m}$ & a: $1.75, \mathrm{~m}$ & a: $1.73, \mathrm{~m}$ & a: $1.77, \mathrm{~m}$ \\
\hline & b: $1.08, \mathrm{qd}(12.7,3.6)$ & b: $1.01, \mathrm{qd}(12.9,3.7)$ & b: $1.19, \mathrm{~m}$ & b: $0.96, \mathrm{~m}$ & $\mathrm{~b}: 1.03, \mathrm{~m}$ & b: 1.12 , qd $(13.0,3.3)$ \\
\hline 8 & $1.41, \mathrm{~m}$ & $1.63, \mathrm{~m}$ & & $1.48, \mathrm{~m}$ & $1.48, \mathrm{~m}$ & $1.42, \mathrm{~m}$ \\
\hline 9 & $2.92, \operatorname{td}(9.9,5.8)$ & $\begin{array}{l}\text { a: } 1.91, \mathrm{dq}(12.6,3.5) \\
\text { b: } 0.93, \mathrm{q}(12.3)\end{array}$ & $\begin{array}{l}\text { a: } 1.75, \mathrm{~m} \\
\text { b: } 1.28, \mathrm{~m}\end{array}$ & $\begin{array}{l}\text { a: } 1.77, \mathrm{~m} \\
\text { b: } 0.87, \mathrm{q}(12.2)\end{array}$ & $3.29, \mathrm{t}(9.0)$ & $2.92, \mathrm{t}(9.9)$ \\
\hline 10 & $1.65, \mathrm{tt}(10.4,2.3)$ & $1.74, \mathrm{~m}$ & $2.15, \operatorname{ddd}(13.3,10.2,3.5)$ & $1.71, \mathrm{~m}$ & $1.61, \operatorname{td}(10.8,9.0)$ & $1.73, \mathrm{tt}(10.3,2.3)$ \\
\hline 11 & $6.24, \mathrm{dd}(10.0,2.4)$ & $5.67, \mathrm{dd}(9.8,1.5)$ & 5.63, brs & $5.59, \mathrm{dd}(9.9,2.5)$ & $4.38, \mathrm{t}(10.5)$ & $6.11, \mathrm{dd}(10.0,2.0)$ \\
\hline 12 & $5.69, \mathrm{dd}(10.0,2.6)$ & $5.61, \mathrm{dd}(9.8,2.5)$ & 5.63, brs & $5.65, \mathrm{dd}(9.8,1.0)$ & $3.78, \mathrm{~d}(10.5)$ & $5.64, \mathrm{dd}(10.0,2.6)$ \\
\hline 14 & $1.26, \mathrm{~s}$ & $1.26, \mathrm{~s}$ & $1.26, \mathrm{~s}$ & $1.25, \mathrm{~s}$ & $1.36, \mathrm{~s}$ & $1.30, \mathrm{~s}$ \\
\hline 15 & $1.03, \mathrm{~d}(6.5)$ & $\begin{array}{l}\text { a: } 3.50, \mathrm{dd}(10.3,6.3) \\
\text { b: } 3.47, \mathrm{dd}(10.3,6.3)\end{array}$ & $1.25, \mathrm{~s}$ & $0.91, \mathrm{~d}(6.6)$ & $1.06, \mathrm{~d}(6.5)$ & $1.03, \mathrm{~d}(6.5)$ \\
\hline 9-OH & $1.55, \mathrm{~d}(6.3)$ & & & & & \\
\hline
\end{tabular}

${ }^{*}$ Chemical shifts were measured at $500.13 \mathrm{MHz}$ in $\mathrm{CDCl}_{3} ;{ }^{* *}$ Chemical shifts were measured at $700.13 \mathrm{MHz}$ in $\mathrm{CDCl}_{3}$. 
Esterification of 1 with $(R)$ - and (S)-MTPA chloride occurred at the C-9 hydroxy group to give the $(S)$ - and (R)-MTPA esters $\mathbf{1 a}$ and $\mathbf{1} \mathbf{b}$, respectively. The observed chemical shift differences $\Delta \delta$ $\left(\delta_{S}-\delta_{R}\right)$ (Figure 3 ) indicated the $9 R$ configuration. These data and observed NOESY correlations determined the absolute stereostructure of $\mathbf{1}$ as $4 R, 5 S, 8 S, 9 R, 10 R$, and 13S. Compound $\mathbf{1}$ was named zosteropenilline A.

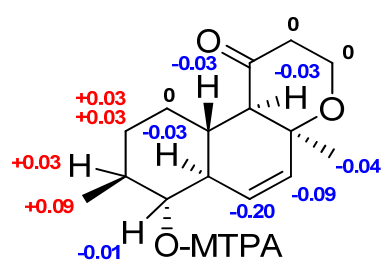

Figure 3. $\Delta \delta\left(\delta_{S}-\delta_{R}\right)$ values (in ppm) for the $(S)$ - and (R)-MPTA esters of 1.

The molecular formula of 2 was established to be $\mathrm{C}_{15} \mathrm{H}_{22} \mathrm{O}_{3}$ from a HRESIMS peak at $m / z 273.1474$ $[\mathrm{M}+\mathrm{Na}]^{+}$and by ${ }^{13} \mathrm{C}$ NMR analyses. The general features of the ${ }^{13} \mathrm{C}$ NMR of $\mathbf{2}$ resembled those of $\mathbf{1}$ with the exception of the C-9-C-11 and C-15 carbon signals. COSY and HSQC spectra of 2 revealed the partially connectivity sequence of the protons in the A ring as $\mathrm{CH}_{2}(15)-\mathrm{CH}(8)-\mathrm{CH}_{2}(9)-\mathrm{CH}(10)$. These data and HMBC correlations from H-9b $\left(\delta_{\mathrm{H}} 0.93\right)$ to C-7 $\left(\delta_{\mathrm{C}} 29.1\right), \mathrm{C}-8\left(\delta_{\mathrm{C}} 40.5\right), \mathrm{C}-10\left(\delta_{\mathrm{C}} 41.4\right), \mathrm{C}-11$ $\left(\delta_{C} 134.4\right)$, and $C-15\left(\delta_{C} 68.1\right)$; and from $\mathrm{H}_{2}-15\left(\delta_{\mathrm{H}} 3.50,3.47\right)$ to $\mathrm{C}-7, \mathrm{C}-8$ and $\mathrm{C}-9$, established the A ring structure, lacking the hydroxy group at $\mathrm{C}-9$, and indicated the presence of a hydroxymethyl group at $\mathrm{C}-8$ in 2 . The NOESY cross-peaks $\mathrm{H}-4\left(\delta_{\mathrm{H}} 2.07\right) / \mathrm{H}-10\left(\delta_{\mathrm{H}} 1.74\right), \mathrm{H}_{3}-14\left(\delta_{\mathrm{H}} 1.26\right) ; \mathrm{H}-8\left(\delta_{\mathrm{H}} 1.63\right) / \mathrm{H}-9 \alpha$ $\left(\delta_{\mathrm{H}} 1.91\right), \mathrm{H}-10 ; \mathrm{H}-5\left(\delta_{\mathrm{H}} 1.78\right) / \mathrm{H}-9 \beta\left(\delta_{\mathrm{H}} 0.93\right) ; \mathrm{H}-9 \beta / \mathrm{H}_{2}-15\left(\delta_{\mathrm{H}} 3.50,3.47\right)$ indicated the trans-ring fusion of the $\mathrm{A}$ and $\mathrm{B}$ ring, cis-ring fusion of the $\mathrm{B}$ and $\mathrm{C}$ ring, and the $\beta$-orientation of hydroxymethyl group at C-8. Compound 2 was named zosteropenilline $B$.

The molecular formula of 3 was established to be $\mathrm{C}_{15} \mathrm{H}_{22} \mathrm{O}_{3}$ from a HRESIMS peak at $m / z 273.1463$ $[\mathrm{M}+\mathrm{Na}]^{+}$and by ${ }^{13} \mathrm{C}$ NMR analyses. The ${ }^{1} \mathrm{H}$ and ${ }^{13} \mathrm{C}$ NMR spectra (Tables 1 and 2 ) for this compound were very similar to those obtained for zosteropenilline B (2) with the exception of the C-6-C-10 and C-15 carbon and proton signals. The HMBC correlations H-9a $\left(\delta_{\mathrm{H}} 1.75\right) / \mathrm{C}-8\left(\delta_{\mathrm{C}} 69.7\right), \mathrm{C}-10\left(\delta_{\mathrm{C}} 36.9\right)$; $\mathrm{H}_{3}-15\left(\delta_{\mathrm{H}} 1.25\right) / \mathrm{C}-7\left(\delta_{\mathrm{C}} 24.9\right), \mathrm{C}-8, \mathrm{C}-9\left(\delta_{\mathrm{C}} 44.5\right)$ established the structure of 3 including the hydroxy and methyl groups at the $\mathrm{C}-8$ position. The relative configuration of 3 was defined based on the observed NOESY correlations (Figure S27). Compound 3 was named zosteropenilline C.

The molecular formula of 4 was established to be $\mathrm{C}_{15} \mathrm{H}_{22} \mathrm{O}_{2}$ from a HRESIMS peak at $m / z 257.1510$ $[\mathrm{M}+\mathrm{Na}]^{+}$and by ${ }^{13} \mathrm{C} \mathrm{NMR}$ analyses. The ${ }^{1} \mathrm{H}$ and ${ }^{13} \mathrm{C}$ NMR data (Tables 1 and 2 ) observed for 4 closely resembled those obtained for zosteropenilline B (2) with the exception of the C-7-C-9 and C-15 carbon and proton signals. The mutual correlations from $\mathrm{H}_{3}-15$ to $\mathrm{C}-7$ and C-9 established the structure of the A ring and location methyl group at C-8. Compound 4 was named zosteropenilline D.

The absolute configurations of zosteropenillines B-D (2-4) were determined on the basis of the ECD spectroscopy data. The geometry of the stable conformations of compounds 1-4 were optimized using general procedure, described in the experimental section of the paper. The internal rotations of the hydroxyl groups as well as the inversions of the six-membered rings $\mathrm{A}$ and $\mathrm{C}$ were accounted for during fulfilled conformational analysis. We found that for all these compounds ring $C$ can exist in two stable conformations: "chair" and "boat". The "chair" conformation is more stable for about $\Delta \mathrm{E}^{\#}$ (chair $\rightarrow$ boat $) \approx 2 \mathrm{kcal} \cdot \mathrm{mol}^{-1}$ and the barrier for interconversion between conformations is $\Delta \mathrm{E}^{\#}$ (chair $\rightarrow$ boat $) \approx 6 \mathrm{kcal} \cdot \mathrm{mol}^{-1}$. Analogously, ring A can also exist in "chair" and "boat" conformations. The "chair" conformation is more stable for about $\Delta \mathrm{E}^{\#}$ (chair $\rightarrow$ boat) $\approx 10 \mathrm{kcal} \cdot \mathrm{mol}^{-1}$ and the barrier for interconversion between conformations is $\Delta \mathrm{E}^{\#}$ (chair $\rightarrow$ boat) $\approx 14 \mathrm{kcal} \cdot \mathrm{mol}^{-1}$ (Figures 4 and 5 ). 

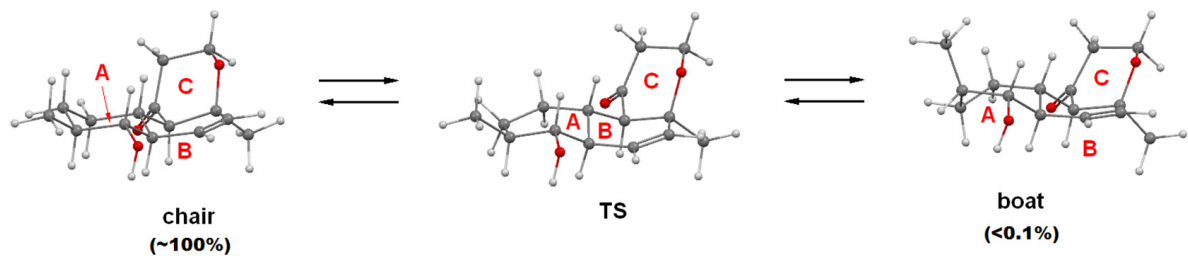

Figure 4. The inversion of A-ring $4 R, 5 S, 8 S, 9 R, 10 R, 13 S$ of $\mathbf{1}$.

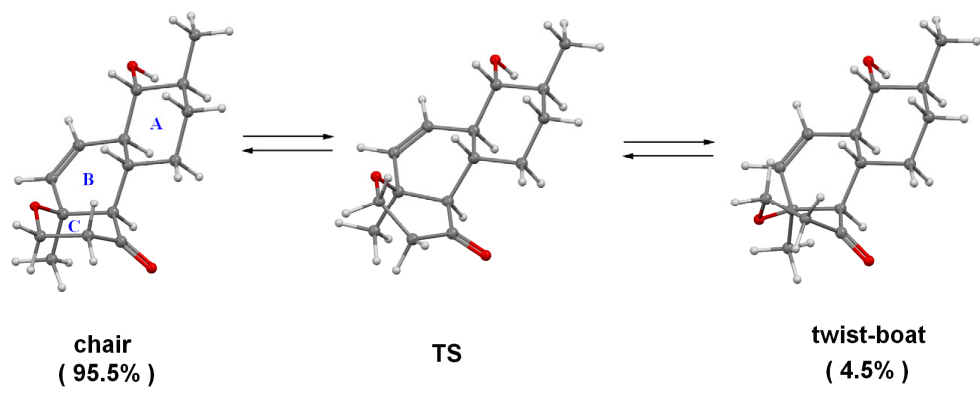

Figure 5. The inversion of C-ring for $4 R, 5 S, 8 S, 9 R, 10 R, 13 S$ of $\mathbf{1}$.

To obtain theoretical ECD spectra the excitation energies and the rotatory strengths for 1-4 were calculated using time-dependent density functional theory (TDDFT) with PBE1PBE exchange-correlation functional and cc-pvTz basis set [8]. A comparison of statistically averaged ECD spectra for 1-4 with corresponding experimental spectra is presented in Figure 6. The comparison of all theoretical spectra with the experimental ones showed that all spectra are qualitatively similar in the region $\lambda \geq 200 \mathrm{~nm}$, where the pronounced Cotton effects occur, thus proving $4 R, 5 S, 8 S, 9 R, 10 R$, $13 S$ absolute configuration for $1 ; 4 R, 5 S, 8 S, 10 R, 13 S$ for $2 ; 4 R, 5 S, 8 R, 10 R, 13 S$ for $3 ; 4 R, 5 S, 8 S, 10 R$, $13 S$ for 4.

A

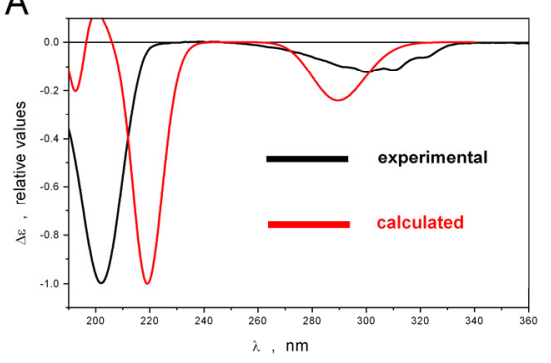

C

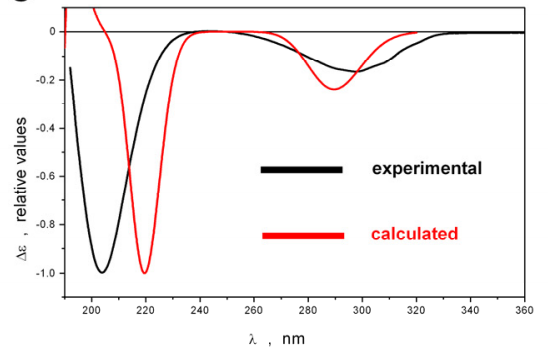

B

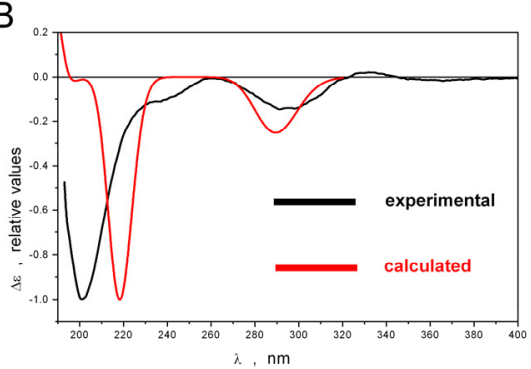

D

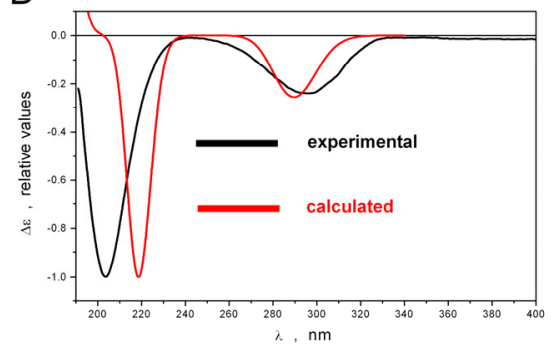

Figure 6. The normalized experimental and statistically averaged ECD spectra. (A) $4 R, 5 S, 8 S, 9 R, 10 R$, 13S-1; (B) 4R, 5S, 8S, 10R, 13S-2; (C) 4R, 5S, 8R, 10R, 13S-3; (D) 4R, 5S, 8S, 10R, 13S-4. The half-width bands $\Delta \mathrm{E}_{\text {excitation }}=0.20 \mathrm{eV}$ were used for the simulations of individual bands in theoretical spectra for each conformer. 
The molecular formula of 5 was established to be $\mathrm{C}_{15} \mathrm{H}_{24} \mathrm{O}_{3}$ from a HRESIMS peak at $m / z 283.1538$ $[\mathrm{M}-\mathrm{H}]^{-}$and by ${ }^{13} \mathrm{C}$ NMR analyses. The COSY-45 data and HMBC correlations from $\mathrm{H}-4\left(\delta_{\mathrm{H}} 2.11\right)$ to $\mathrm{C}-5\left(\delta_{\mathrm{C}} 38.5\right), \mathrm{C}-6\left(\delta_{\mathrm{C}} 29.0\right), \mathrm{C}-10\left(\delta_{\mathrm{C}} 53.5\right)$, from $\mathrm{H}-5\left(\delta_{\mathrm{H}} 1.95\right)$ to $\mathrm{C}-6, \mathrm{C}-10$, from H-6a $\left(\delta_{\mathrm{H}} 1.33\right)$ to $\mathrm{C}-4\left(\delta_{\mathrm{C}} 63.7\right), \mathrm{C}-7\left(\delta_{\mathrm{C}} 31.8\right)$ and $\mathrm{C}-10$, from $\mathrm{H}-7 \mathrm{a}\left(\delta_{\mathrm{H}} 1.73\right)$ to $\mathrm{C}-5, \mathrm{C}-9\left(\delta_{\mathrm{C}} 77.2\right)$, from $\mathrm{H}_{3}-15\left(\delta_{\mathrm{H}} 1.06\right)$ to C-7, C-8 $\left(\delta_{C} 39.2\right)$, C-9, from H-9 $\left(\delta_{H} 3.29\right)$ to C-5, C-11 $\left(\delta_{C} 67.3\right)$, from H-10 $\left(\delta_{H} 1.61\right)$ to C-5, C-9, C-11, from $\mathrm{H}-11\left(\delta_{\mathrm{H}} 4.38\right)$ to $\mathrm{C}-12\left(\delta_{\mathrm{C}} 72.7\right)$, and from $\mathrm{H}_{3}-14\left(\delta_{\mathrm{H}} 1.36\right)$ to $\mathrm{C}-4, \mathrm{C}-12, \mathrm{C}-13\left(\delta_{\mathrm{C}} 77.5\right)$ revealed the presence of a decalin moiety in $\mathbf{1}$ and established the location of methyl groups at C-8 and C-13 and hydroxy groups at C-9, C-11 and C-12. HMBC correlations from H-1a $\left(\delta_{\mathrm{H}} 4.22\right)$ to $\mathrm{C}-2\left(\delta_{\mathrm{C}} 37.9\right)$, $\mathrm{C}-3\left(\delta_{\mathrm{C}} 206.0\right)$ and $\mathrm{C}-13$, from $\mathrm{H}-2 \mathrm{a}\left(\delta_{\mathrm{H}} 2.67\right)$ to $\mathrm{C}-1\left(\delta_{\mathrm{C}} 60.9\right), \mathrm{C}-3$, from $\mathrm{H}-4\left(\delta_{\mathrm{H}} 2.11\right)$ to $\mathrm{C}-2$ and $\mathrm{C}-3$ established a saturated $\gamma$-pyrone derivative in 5 (Figure S40). The relative configuration of 5 was assigned based on NOESY cross-peaks (Figure 7) and ${ }^{1} \mathrm{H}-{ }^{1} \mathrm{H}$ coupling constants (Table 2). Observed NOESY correlations and magnitudes of the vicinal coupling constants between $\mathrm{H}-4$ and $\mathrm{H}-5$; $\mathrm{H}-5$ and $\mathrm{H}-10 ; \mathrm{H}-9$ and $\mathrm{H}-10 ; \mathrm{H}-10$ and $\mathrm{H}-11 ; \mathrm{H}-11$ and $\mathrm{H}-12$ indicated a trans-ring fusion of the $\mathrm{A}$ and $\mathrm{B}$ rings, cis-ring fusion of the $\mathrm{B}$ and $\mathrm{C}$ rings, the $\alpha$-orientation of $\mathrm{H}_{3}-14,9-\mathrm{OH}, 11-\mathrm{OH}$ groups and the $\beta$-orientation of $\mathrm{H}_{3}-15$ and $12-\mathrm{OH}$ groups. Compound 5 was named zosteropenilline $\mathrm{E}$.

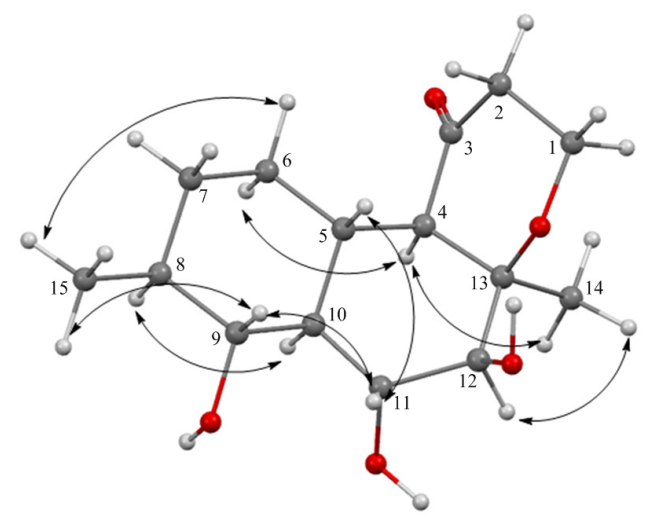

Figure 7. Energy-minimized 3D model of 5 with key NOESY correlations.

The molecular formula of 6 was established to be $\mathrm{C}_{15} \mathrm{H}_{24} \mathrm{O}_{4}$ from a HRESIMS peak at $\mathrm{m} / \mathrm{z}$ $291.1579[\mathrm{M}+\mathrm{Na}]^{+}$and by ${ }^{13} \mathrm{C}$ NMR analyses. The ${ }^{13} \mathrm{C}$ NMR data of 6 matched those for $\mathbf{1}$ with the exception of the C-1-C-3 and C-13-C-14 carbon signals. The structure of the decalin moiety and location of the methyl groups at C-8 and C-13 and oxygen functions at C-9 and C-13 were established as for zosteropenilline A (1) based on COSY and HMBC correlations. The COSY-45 data and HMBC correlations from $\mathrm{H}_{2}-1\left(\delta_{\mathrm{H}} 3.91\right)$ to $\mathrm{C}-2\left(\delta_{\mathrm{C}} 48.6\right)$ and $\mathrm{C}-3\left(\delta_{\mathrm{C}} 217.6\right)$, from $\mathrm{H}_{2}-2\left(\delta_{\mathrm{H}} 2.86,2.76\right)$ to $\mathrm{C}-1$ $\left(\delta_{\mathrm{C}} 57.6\right)$ and $\mathrm{C}-3$, and from $\mathrm{H}-4\left(\delta_{\mathrm{H}} 2.59\right)$ to $\mathrm{C}-3$ indicated the presence of a 3-hydroxy-1-oxopropyl residue (C-1-C-3 residue numbering) at C-4. The relative configuration of 6 was assigned on the basis of a NOESY experiment and ${ }^{1} \mathrm{H}-{ }^{1} \mathrm{H}$ coupling constants (Table 2). Compound 6 was named zosteropenilline F. Zosteropenilline $\mathrm{F}$ is an epimer of the pallidopenilline A (13) which was earlier isolated from the $P$. thomii associated with the brown alga Sargassum pallidum [7]. The ${ }^{1} \mathrm{H}$ and ${ }^{13} \mathrm{C}$ NMR data observed for 6 closely resembled those obtained for pallidopenilline A (measured in $\mathrm{CDCl}_{3}$ ) (Figures S58-S68) with the exception of the C-4, C-13 and C-14 carbon and proton signals The molecular formula of 7 was established to be $\mathrm{C}_{15} \mathrm{H}_{24} \mathrm{O}_{3}$ from a HRESIMS peak at $m / z 275.1621[\mathrm{M}+\mathrm{Na}]^{+}$and by ${ }^{13} \mathrm{C}$ NMR analyses. The ${ }^{13} \mathrm{C}$ NMR data (Table 3) observed for 7 closely resembled those obtained for zosteropenilline D (4) with the exception of the C-1-C-3 and C-13-C-14 carbon signals. The structure of the decalin moiety, location of the methyl groups at C-8 and C-13, oxygen functions at C-13 and 3-hydroxy-1-oxopropyl residue at C-4 were established by HMBC and COSY correlations (Figures S74 and S75). The relative configuration of 7 was assigned based on NOESY correlations $\mathrm{H}-4\left(\delta_{\mathrm{H}} 2.89\right) / \mathrm{H}-10\left(\delta_{\mathrm{H}} 1.84\right) ; \mathrm{H}-10 / \mathrm{H}-8\left(\delta_{\mathrm{H}} 1.46\right)$ and $\mathrm{H}-5\left(\delta_{\mathrm{H}} 1.48\right) / \mathrm{H}_{3}-14\left(\delta_{\mathrm{H}} 1.20\right)$ and $\mathrm{H}_{3}-15\left(\delta_{\mathrm{H}}\right.$ 
$0.89)$ recorded in $\mathrm{CDCl}_{3}$ and $13-\mathrm{OH}\left(\delta_{\mathrm{H}} 4.95\right) / \mathrm{H}-4$ correlation in spectrum of 7 recorded in DMSO- $d_{6}$ (Figure S77). Compound 7 was named zosteropenilline G.

Table 3. ${ }^{13} \mathrm{C}$ NMR spectroscopic data ( $\delta$ in ppm) for zosteropenillines G-L (7-12).

\begin{tabular}{|c|c|c|c|c|c|c|}
\hline Position & $7 *$ & $8^{* *}$ & $9 *$ & $10 * *$ & $11 *$ & $12 * *$ \\
\hline 1 & $58.1, \mathrm{CH}_{2}$ & $57.9, \mathrm{CH}_{2}$ & $58.0, \mathrm{CH}_{2}$ & $58.0, \mathrm{CH}_{2}$ & $57.9, \mathrm{CH}_{2}$ & $58.0, \mathrm{CH}_{2}$ \\
\hline 2 & $49.3, \mathrm{CH}_{2}$ & $43.6, \mathrm{CH}_{2}$ & $42.1, \mathrm{CH}_{2}$ & $49.2, \mathrm{CH}_{2}$ & $48.9, \mathrm{CH}_{2}$ & $49.5, \mathrm{CH}_{2}$ \\
\hline 3 & $214.3, \mathrm{C}$ & $214.0, C$ & $213.5, \mathrm{C}$ & $214.1, \mathrm{C}$ & $211.2, \mathrm{C}$ & $213.2, \mathrm{C}$ \\
\hline 4 & $63.5, \mathrm{CH}$ & 61.7, CH & $59.6, \mathrm{CH}$ & $63.4, \mathrm{CH}$ & 61.6, CH & $57.7, \mathrm{CH}$ \\
\hline 5 & $41.3, \mathrm{CH}$ & $37.9, \mathrm{CH}$ & $40.3, \mathrm{CH}$ & $41.5, \mathrm{CH}$ & $39.4, \mathrm{CH}$ & $40.3, \mathrm{CH}$ \\
\hline 6 & $29.4, \mathrm{CH}_{2}$ & $30.5, \mathrm{CH}_{2}$ & $29.9, \mathrm{CH}_{2}$ & 28.7, $\mathrm{CH}_{2}$ & $32.4, \mathrm{CH}_{2}$ & $32.1, \mathrm{CH}_{2}$ \\
\hline 7 & $34.8, \mathrm{CH}_{2}$ & $31.9, \mathrm{CH}_{2}$ & $32.6, \mathrm{CH}_{2}$ & $28.9, \mathrm{CH}_{2}$ & $27.9, \mathrm{CH}_{2}$ & $28.1, \mathrm{CH}_{2}$ \\
\hline 8 & $32.9, \mathrm{CH}$ & $39.2, \mathrm{CH}$ & $40.4, \mathrm{CH}$ & $40.6, \mathrm{CH}$ & $41.1, \mathrm{CH}$ & $41.1, \mathrm{CH}$ \\
\hline 9 & $40.9, \mathrm{CH}_{2}$ & $82.3, \mathrm{CH}$ & $78.3, \mathrm{CH}$ & $35.2, \mathrm{CH}_{2}$ & $38.3, \mathrm{CH}_{2}$ & $37.2, \mathrm{CH}_{2}$ \\
\hline 10 & $42.1, \mathrm{CH}$ & $49.6, \mathrm{CH}$ & $47.2, \mathrm{CH}$ & $41.5, \mathrm{CH}$ & $166.3, \mathrm{C}$ & $144.5, \mathrm{C}$ \\
\hline 11 & $131.9, \mathrm{CH}$ & $73.2, \mathrm{CH}$ & $130.6, \mathrm{CH}$ & $131.5, \mathrm{CH}$ & $120.0, \mathrm{CH}$ & $118.8, \mathrm{CH}$ \\
\hline 12 & $133.7, \mathrm{CH}$ & $129.0, \mathrm{CH}$ & $129.3, \mathrm{CH}$ & 134.0, $\mathrm{CH}$ & $200.3, C$ & $68.0, \mathrm{CH}$ \\
\hline 13 & 73.0, C & $131.5, \mathrm{C}$ & $140.8, \mathrm{C}$ & $72.9, \mathrm{C}$ & $74.2, \mathrm{C}$ & $72.4, \mathrm{C}$ \\
\hline 14 & $25.9, \mathrm{CH}_{3}$ & $20.9, \mathrm{CH}_{3}$ & $112.8, \mathrm{CH}_{2}$ & $25.9, \mathrm{CH}_{3}$ & $21.8, \mathrm{CH}_{3}$ & $20.5, \mathrm{CH}_{3}$ \\
\hline 15 & 22.3, $\mathrm{CH}_{3}$ & $17.8, \mathrm{CH}_{3}$ & $18.4, \mathrm{CH}_{3}$ & $68.1, \mathrm{CH}_{2}$ & $67.4, \mathrm{CH}_{2}$ & $67.8, \mathrm{CH}_{2}$ \\
\hline
\end{tabular}

${ }^{*}$ Chemical shifts were measured at $125.77 \mathrm{MHz}$ in $\mathrm{CDCl}_{3} ;{ }^{* *}$ Chemical shifts were measured at $176.04 \mathrm{MHz}$ in CDCl$l_{3}$.

The molecular formula of 8 was established to be $\mathrm{C}_{15} \mathrm{H}_{24} \mathrm{O}_{4}$ from a HRESIMS peak at $m / z$ 291.1571 [M + Na $]^{+}$and by ${ }^{13} \mathrm{C}$ NMR analyses. The ${ }^{1} \mathrm{H}$ NMR, ${ }^{13} \mathrm{C}$ NMR, DEPT and HSQC spectra of 8 (Tables 3 and 4 ) displayed obvious signals for two methyl $\left(\delta_{\mathrm{H}} 1.60, \delta_{\mathrm{C}} 20.9\right.$ and $\left.\delta_{\mathrm{H}} 1.02, \delta_{\mathrm{C}} 17.8\right)$ groups, four methylenes $\left(\delta_{\mathrm{C}} 43.6,30.5,31.9\right)$ including one oxygen-bearing $\left(\delta_{\mathrm{H}} 3.85,2 \mathrm{H}, \delta_{\mathrm{C}} 57.9\right)$, seven methines $\left(\delta_{\mathrm{H}} 1.69, \delta_{\mathrm{C}} 37.9, \delta_{\mathrm{H}} 1.47, \delta_{\mathrm{C}} 39.2, \delta_{\mathrm{H}} 1.28, \delta_{\mathrm{C}} 49.6, \delta_{\mathrm{H}} 2.92, \delta_{\mathrm{C}} 61.7, \delta_{\mathrm{H}} 3.25, \delta_{\mathrm{C}} 82.3, \delta_{\mathrm{H}}\right.$ $4.32, \delta_{\mathrm{C}} 73.2, \delta_{\mathrm{H}} 5.53, \delta_{\mathrm{C}} 129.0$,) including two oxygen-bearing, one carbonyl carbon $\left(\delta_{\mathrm{C}} 214.0\right)$ and one $s p^{3}$ quaternary carbon $\left(\delta_{C}\right.$ 131.5). The structure of a 1,2,3,4-tetrasubstituted cyclohexane ring and side chain in 8 were found by extensive NMR spectroscopy $\left({ }^{1} \mathrm{H}\right.$ and ${ }^{13} \mathrm{C}$ NMR, COSY, HSQC and $\mathrm{HMBC}$ ) as for zosteropenillines $\mathrm{E}(5)$ and $\mathrm{F}(6)$. HMBC correlations from H-4 $\left(\delta_{\mathrm{H}} 2.92\right)$ to C-5 ( $\left.\delta_{\mathrm{C}} 37.9\right)$, $\mathrm{C}-12\left(\delta_{\mathrm{C}} 129.0\right), \mathrm{C}-13\left(\delta_{\mathrm{C}} 131.5\right)$, from H-10 $\left(\delta_{\mathrm{H}} 1.28\right)$ to $\mathrm{C}-5, \mathrm{C}-11\left(\delta_{\mathrm{C}} 73.2\right), \mathrm{C}-12$, from H-11 $\left(\delta_{\mathrm{H}} 4.32\right)$ to $\mathrm{C}-12, \mathrm{C}-13$, and from $\mathrm{H}_{3}-14\left(\delta_{\mathrm{H}} 1.60\right)$ to $\mathrm{C}-4\left(\delta_{\mathrm{C}} 61.7\right), \mathrm{C}-12, \mathrm{C}-13$ established a $\mathrm{B}$ ring structure, $\Delta^{12}$ double bond and the location of the hydroxy group at C-11. The relative configuration of 8 was assigned based on NOESY cross-peaks H-4/H-10; H-5 $\left(\delta_{\mathrm{H}} 1.69\right) / \mathrm{H}-9\left(\delta_{\mathrm{H}} 3.25\right), \mathrm{H}-11, \mathrm{H}_{3}-15\left(\delta_{\mathrm{H}} 1.02\right)$; $\mathrm{H}-8\left(\delta_{\mathrm{H}} 1.47\right) / \mathrm{H}-10 ; \mathrm{H}-9 / \mathrm{H}-11$ and ${ }^{1} \mathrm{H}-{ }^{1} \mathrm{H}$ coupling constants (Table 4$)$. Compound 8 was named zosteropenilline $\mathrm{H}$.

The molecular formula of 9 was established to be $\mathrm{C}_{15} \mathrm{H}_{22} \mathrm{O}_{3}$ from a HRESIMS peak at $m / z 273.1462$ $[\mathrm{M}+\mathrm{Na}]^{+}$and by ${ }^{13} \mathrm{C}$ NMR analyses. Structures of an A ring and side chain in 9 were established as for zosteropenillines $\mathrm{E}(5)$ and $\mathrm{F}(6)$. Observed long-range COSY correlations $\mathrm{H}-4\left(\delta_{\mathrm{H}} 3.15\right) / \mathrm{H}_{2}-14$ $\left(\delta_{\mathrm{H}} 4.99,4.59\right), \mathrm{H}-12\left(\delta_{\mathrm{H}} 6.20\right) / \mathrm{H}-14 \mathrm{~b}$. and HMBC correlations from H-4 $\left(\delta_{\mathrm{H}} 3.15\right)$ to C-13 $\left(\delta_{\mathrm{C}} 140.8\right)$, $\mathrm{C}-14\left(\delta_{\mathrm{C}} 112.8\right)$, from $\mathrm{H}-9\left(\delta_{\mathrm{H}} 2.89\right)$ and $\mathrm{H}-10\left(\delta_{\mathrm{H}} 1.85\right)$ to $\mathrm{C}-11\left(\delta_{\mathrm{C}} 130.6\right)$ and from $\mathrm{H}_{2}-14\left(\delta_{\mathrm{H}} 4.99,4.59\right)$ to $\mathrm{C}-4\left(\delta_{\mathrm{C}} 59.6\right), \mathrm{C}-12\left(\delta_{\mathrm{C}} 129.3\right), \mathrm{C}-13$ indicated the presence of a diene system at the C-11 and C-13(14) in 9. The relative configuration of 9 was assigned based on the NOESY correlations $\mathrm{H}-4 / \mathrm{H}-10 ; \mathrm{H}-8$ $\left(\delta_{\mathrm{H}} 1.43\right) / \mathrm{H}-10$ and $\mathrm{H}-5\left(\delta_{\mathrm{H}} 1.68\right) / \mathrm{H}-9, \mathrm{H}_{3}-15\left(\delta_{\mathrm{H}} 1.05\right)$. Compound 9 was named zosteropenilline $\mathrm{I}$. 
Table 4. ${ }^{1} \mathrm{H}$ NMR spectroscopic data $(\delta, J$ in $\mathrm{Hz}$ ) for zosteropenillines G-L (7-12).

\begin{tabular}{|c|c|c|c|c|c|c|}
\hline Position & 7 * & $8^{* *}$ & $9 *$ & 10 ** & 11 * & $12 * * *$ \\
\hline \multirow{2}{*}{1} & a: 3.90, ddd $(11.7,7.1,3.7)$ & & a: $3.91, \operatorname{ddd}(11.5,7.1,3.9)$ & a: 3.91, ddd $(11.2,6.9,3.6)$ & a: 3.96, ddd $(11.5,7.7,3.7)$ & a: 3.95, ddd $(11.3,7.5,3.5)$ \\
\hline & b: 3.86, ddd $(11.7,6.6,3.7)$ & $3.85, \mathrm{~m}(2 \mathrm{H})$ & b: 3.85, ddd $(11.5,6.8,4.2)$ & b: 3.87, ddd $(11.2,6.7,3.7)$ & b: 3.82, ddd $(11.5,6.7,3.9)$ & b: 3.82, ddd $(11.3,6.4,3.6)$ \\
\hline \multirow{2}{*}{2} & a: $3.04, \mathrm{ddd}(18.0,6.8,3.8)$ & a: $2.69, \mathrm{ddd}(18.2,6.6,4.3)$ & a: $2.83, \mathrm{ddd}(18.3,6.8,3.8)$ & a: 3.06, ddd $(18.0,7.1,3.7)$ & a: $3.14, \mathrm{ddd}(18.0,6.5,3.6)$ & a: 3.05, ddd $(18.1,6.5,3.6)$ \\
\hline & b: 2.60, ddd $(18.0,7.1,3.8)$ & b: 2.64, ddd $(18.2,6.3,4.3)$ & b: 2.65, ddd $(18.3,6.8,4.0)$ & b: 2.61, ddd $(18.0,7.0,3.7)$ & b: 2.66, ddd $(18.0,7.6,3.9)$ & b: 2.69, ddd $(18.0,7.6,3.7)$ \\
\hline 4 & $2.89, \mathrm{~d}(11.5)$ & $2.92, \mathrm{~m}$ & $3.15, \mathrm{dtd}(12.1,2.6,0.9)$ & $2.92, \mathrm{~d}(11.6)$ & $3.01, \mathrm{~d}(9.8)$ & $3.09, \mathrm{~d}(10.0)$ \\
\hline 5 & $1.48, \mathrm{~m}$ & $1.69, \mathrm{~m}$ & $1.68, \mathrm{~m}$ & $1.52, \mathrm{dq}(11.7,2.7)$ & $2.89, \mathrm{~m}$ & $2.55, \mathrm{~m}$ \\
\hline \multirow{2}{*}{6} & a: $1.70, \mathrm{~m}$ & a: $1.57, \mathrm{dq}(13.2,3.5)$ & a: $1.53, \mathrm{~m}$ & a: $1.79, \mathrm{~m}$ & a: $1.91, \mathrm{dq}(12.9,3.0)$ & a: $1.74, \mathrm{~m}$ \\
\hline & b: $0.93, \mathrm{~m}$ & b: 1.17 , qd $(13.1,3.5)$ & $\mathrm{b}: 1.14, \mathrm{~m}$ & b: $0.95, \mathrm{qd}(12.3,3.6)$ & b: 1.15 , qd $(13.1,3.3)$ & $\mathrm{b}: 1.12, \mathrm{~m}$ \\
\hline \multirow[b]{2}{*}{7} & $\mathrm{a}: 1.71, \mathrm{~m}$ & a: $1.70, \mathrm{~m}$ & a: $1.77, \mathrm{~m}$ & a: $1.79, \mathrm{~m}$ & a: $1.84, \mathrm{dq}(13.1,3.2)$ & a: $1.79, \mathrm{~m}$ \\
\hline & b: $0.96, \mathrm{~m}$ & b: $1.03, \mathrm{qd}(13.2,3.5)$ & b: $1.10, \mathrm{~m}$ & b: $1.02, \mathrm{qd}(12.4,3.6)$ & b: $1.29, \mathrm{~m}$ & b: $1.12, \mathrm{~m}$ \\
\hline 8 & $1.46, \mathrm{~m}$ & $1.47, \mathrm{~m}$ & $1.43, \mathrm{~m}$ & $1.61, \mathrm{~m}$ & $1.74, \mathrm{~m}$ & $1.64, \mathrm{~m}$ \\
\hline 9 & a: $1.73, \mathrm{~m}$ & $3.25, \mathrm{t}(9.3)$ & $2.89, \mathrm{t}(9.9)$ & a: $1.87, \mathrm{~m}$ & a: $2.60, \mathrm{dq}(14.0,2.5)$ & a: $2.39, \mathrm{dq}(13.5,2.5)$ \\
\hline 10 & $\begin{array}{l}\text { b: } 0.77, \mathrm{q}(12.4) \\
1.84, \mathrm{~m}\end{array}$ & $1.28, \mathrm{dt}(11.9,9.3)$ & $1.85, \mathrm{t}(10.0)$ & $\begin{array}{l}\text { b: } 0.82, \mathrm{q}(13.0) \\
1.87, \mathrm{~m}\end{array}$ & b: $2.01, \mathrm{~m}$ & b: $1.77, \mathrm{~m}$ \\
\hline 11 & 5.42, brs & $4.32, \mathrm{dq}(8.9,2.1)$ & 6.20 , brs & 5.44, brs & 5.90, brs & $5.60, \mathrm{dt}(5.9,2.1)$ \\
\hline 12 & 5.42 , brs & $5.53, \mathrm{q}(1.8)$ & 6.20, brs & 5.44 , brs & & $4.36, \mathrm{dd}(5.9,1.7)$ \\
\hline 14 & $1.20, \mathrm{~s}$ & 1.60, brs & $\begin{array}{l}\text { a: } 4.99, \mathrm{dd}(2.8,1.3) \\
\text { b: } 4.59, \mathrm{dt}(2.3,0.9)\end{array}$ & $1.20, \mathrm{~s}$ & $1.19, \mathrm{~s}$ & $1.20, \mathrm{~s}$ \\
\hline 15 & $0.89, \mathrm{~d}(6.5)$ & $1.02, \mathrm{~d}(6.5)$ & $1.05, \mathrm{~d}(6.5)$ & $\begin{array}{l}\text { a: } 3.47, \mathrm{dd}(10.6,6.6) \\
\text { b: } 3.45, \mathrm{dd}(10.6,6.6)\end{array}$ & $\begin{array}{l}\text { a: } 3.58, \mathrm{dd}(10.5,5.8) \\
\text { b: } 3.54, \mathrm{dd}(10.5,5.8)\end{array}$ & $\begin{array}{l}\text { a: } 3.50, \mathrm{dd}(10.5,5.9) \\
\text { b: } 3.48, \mathrm{dd}(10.4,6.2)\end{array}$ \\
\hline
\end{tabular}

${ }^{*}$ Chemical shifts were measured at $500.13 \mathrm{MHz}$ in $\mathrm{CDCl}_{3} ;{ }^{* *}$ Chemical shifts were measured at $700.13 \mathrm{MHz}$ in $\mathrm{CDCl}_{3}$. 
The molecular formula of $\mathbf{1 0}$ was established to be $\mathrm{C}_{15} \mathrm{H}_{24} \mathrm{O}_{4}$ from a HRESIMS peak at $\mathrm{m} / \mathrm{z}$ $291.1573[\mathrm{M}+\mathrm{Na}]^{+}$and by ${ }^{13} \mathrm{C}$ NMR analyses. The ${ }^{13} \mathrm{C}$ NMR data (Table 3) observed for 10 matched the data reported for zosteropenilline $G$ (7) with the exception of the C-7-C-9 and C-15 carbon signals. These data, together with the molecular mass difference of 16 mass units between 7 and 10, indicated the presence of the hydroxymethyl group at C-8 in $\mathbf{1 0}$ instead of a methyl group. NOESY cross-peaks $\mathrm{H}-4\left(\delta_{\mathrm{H}} 2.92\right) / \mathrm{H}-6 \mathrm{~b}\left(\delta_{\mathrm{H}} 0.95\right), \mathrm{H}-10\left(\delta_{\mathrm{H}} 1.87\right) ; \mathrm{H}-5\left(\delta_{\mathrm{H}} 1.52\right) / \mathrm{H}-7 \mathrm{~b}\left(\delta_{\mathrm{H}} 1.02\right), \mathrm{H}-9 \mathrm{~b}\left(\delta_{\mathrm{H}} 0.82\right), \mathrm{H}_{3}-14$ $\left(\delta_{\mathrm{H}} 1.20\right) ; \mathrm{H}-7 \mathrm{~b} / \mathrm{H}-9 \mathrm{~b}, \mathrm{H}_{2}-15\left(\delta_{\mathrm{H}} 3.47,3.45\right) ; \mathrm{H}-8\left(\delta_{\mathrm{H}} 1.61\right) / \mathrm{H}-6 \mathrm{~b}, \mathrm{H}-10$ indicated the trans-ring fusion of the $\mathrm{A}$ and $\mathrm{B}$ rings, a $\beta$-orientation of the side chain, $\mathrm{H}_{3}-14$ and hydroxymethyl group at $\mathrm{C}-8$. Compound 10 was named zosteropenilline J.

The molecular formula of $\mathbf{1 1}$ was established to be $\mathrm{C}_{15} \mathrm{H}_{22} \mathrm{O}_{5}$ from a HRESIMS peak at $\mathrm{m} / \mathrm{z}$ $305.1370[\mathrm{M}+\mathrm{Na}]^{+}$and by ${ }^{13} \mathrm{C}$ NMR analyses. The UV spectrum exhibits a $\lambda_{\max }$ at $242 \mathrm{~nm}$ ( $\log \varepsilon$ 3.46), consistent with the enone system in 11. The COSY and HSQC spectra of 11 revealed the partial connectivity sequences of the protons in the A ring as $\mathrm{CH}(5)-\mathrm{CH}_{2}(6)-\mathrm{CH}_{2}(7)-\mathrm{CH}(8)$ and $\mathrm{CH}_{2}(15)-\mathrm{CH}(8)-\mathrm{CH}_{2}(9)$. These data and $\mathrm{HMBC}$ correlations from $\mathrm{H}-9 \mathrm{a}\left(\delta_{\mathrm{H}} 2.60\right)$ to $\mathrm{C}-7\left(\delta_{\mathrm{C}} 27.9\right), \mathrm{C}-8$ $\left(\delta_{\mathrm{C}} 41.1\right)$ and $\mathrm{C}-15\left(\delta_{\mathrm{C}} 67.4\right)$, from $\mathrm{H}-9 \mathrm{~b}\left(\delta_{\mathrm{H}} 2.01\right)$ to $\mathrm{C}-10\left(\delta_{\mathrm{C}} 166.3\right)$, from $\mathrm{H}_{2}-15\left(\delta_{\mathrm{H}} 3.58,3.54\right)$ to $\mathrm{C}-7$, C-8 and C-9 $\left(\delta_{C} 38.3\right)$ established the structure of A ring. Long range correlations from $\mathrm{H}-4\left(\delta_{\mathrm{H}} 3.01\right)$ to $C-5\left(\delta_{C} 39.4\right), C-10, C-12\left(\delta_{C} 200.3\right)$ and $C-13\left(\delta_{C} 74.2\right)$, from $\mathrm{H}-11\left(\delta_{H} 5.90\right)$ to $C-5$ and $C-13$ and from $\mathrm{H}_{3}-14\left(\delta_{\mathrm{H}} 1.19\right)$ to $\mathrm{C}-4\left(\delta_{\mathrm{C}} 61.6\right), \mathrm{C}-12, \mathrm{C}-13$ determined the structure of $\mathrm{B}$ ring and indicated the 10-en-12-one position for the enone chromophore in $\mathbf{1 1}$. The structure of side chain in $\mathbf{1 1}$ was found by NMR spectroscopy as for zosteropenilline $F(6)$. Observed NOESY correlations $\mathrm{H}-5\left(\delta_{\mathrm{H}} 2.89\right) / \mathrm{H}-9 \mathrm{~b}$ $\left(\delta_{\mathrm{H}} 2.01\right), \mathrm{H}_{3}-14 ; \mathrm{H}_{2}-15 / \mathrm{H}-9 \mathrm{~b}$ indicated these protons to be on the same side of the molecule. These data and the magnitude of the coupling constant of the $\mathrm{H}-4$ signal $\left(\delta_{\mathrm{H}} 3.01, J=9.8 \mathrm{~Hz}\right)$ indicated $\mathrm{H}-4$ and $13-\mathrm{OH}$ to be on the other side of molecule. Compound $\mathbf{1 1}$ was named zosteropenilline $\mathrm{K}$.

The molecular formula of $\mathbf{1 2}$ was established to be $\mathrm{C}_{15} \mathrm{H}_{24} \mathrm{O}_{5}$ from a HRESIMS peak at $\mathrm{m} / \mathrm{z}$ $307.1501[\mathrm{M}+\mathrm{Na}]^{+}$and by ${ }^{13} \mathrm{C}$ NMR analyses. The structure of the A ring in $\mathbf{1 2}$ was established based on COSY and HMBC correlations as for zosteropenilline $\mathrm{K}$ (11). HMBC correlations from $\mathrm{H}-11\left(\delta_{\mathrm{H}} 5.60\right)$ to $\mathrm{C}-5\left(\delta_{\mathrm{C}} 40.3\right), \mathrm{C}-9\left(\delta_{\mathrm{C}} 37.2\right), \mathrm{C}-12\left(\delta_{\mathrm{C}} 68.0\right), \mathrm{C}-13\left(\delta_{\mathrm{C}} 72.4\right)$, from H-12 $\left(\delta_{\mathrm{H}} 4.36\right)$ to $\mathrm{C}-4\left(\delta_{\mathrm{C}} 57.7\right), \mathrm{C}-10\left(\delta_{\mathrm{C}} 144.5\right), \mathrm{C}-11\left(\delta_{\mathrm{C}} 118.8\right), \mathrm{C}-13$, and from $\mathrm{H}_{3}-14\left(\delta_{\mathrm{H}} 1.20\right)$ to $\mathrm{C}-4, \mathrm{C}-12$, C-13 established the structure of B ring, location oxygenated functions at C-12, C-13 and methyl group at $\mathrm{C}-13$ in $\mathbf{1 2}$. The relative configuration of $\mathbf{1 2}$ was defined based on NOESY correlations $\mathrm{H}-5 / \mathrm{H}_{3}-14 ; \mathrm{H}_{3}-14 / \mathrm{H}-12 ; \mathrm{H}-4 / \mathrm{H}-6 \mathrm{~b} ; \mathrm{H}-6 \mathrm{~b} / \mathrm{H}-8$ and the magnitude of the coupling constant of the $\mathrm{H}-4$ signal $\left(\delta_{\mathrm{H}} 3.09, J=10.0 \mathrm{~Hz}\right)$. Compound 12 was named zosteropenilline L. Besides the new zosteropenillines (1-12), a known pallidopenilline A (13) was also isolated from this fungus. For the first time, pallidopenilline A was found in fungus P. thomii KMM 4675 [7].

\subsection{Bioassay Results}

Compounds 2, 8, and $\mathbf{1 0}$ induced a moderate downregulation of NO production in LPS-stimulated macrophages at non-cytotoxic concentration of $10.0 \mu \mathrm{M}$. Respectively, NO levels in these cells were decreased by $27.7 \pm 1.8,20.6 \pm 1.2$, and $22.3 \pm 3.8$ percent, in comparison with LPS-pretreated control cells. The most effective substance was compound 2, which exhibited the maximal pronounced inhibition of NO formation in lipopolysaccharide-stimulated RAW 264.7 cells (Figure 8). 


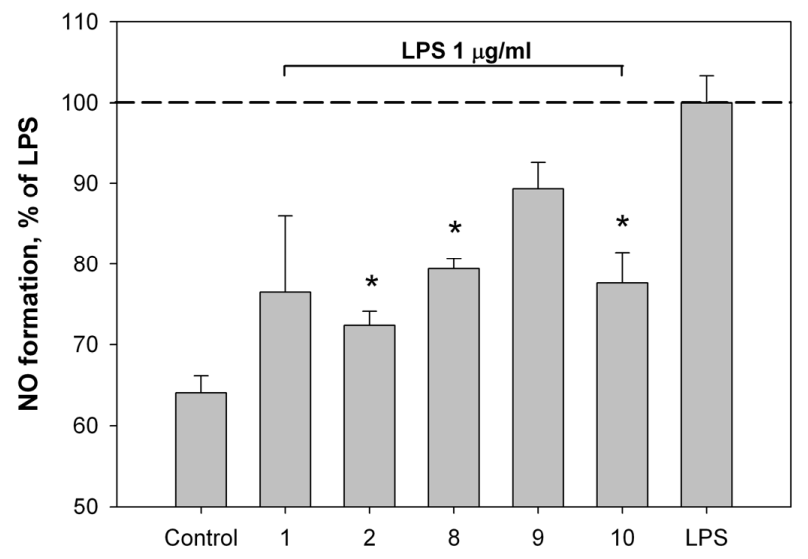

Figure 8. Effect of compounds 1, 2, and 8-10 on NO level in RAW 264.7 murine macrophages co-incubated with LPS from $E$. coli. The compounds were tested at a concentration of $10 \mu \mathrm{M}$. Time of cell incubation with compounds is $24 \mathrm{~h}$ at $37^{\circ} \mathrm{C} .{ }^{*} p<0.01$.

We have investigated the effect of the isolated zosteropenillines 1-3, 7, 8, 10, and 11 on the viability of human drug-resistant prostate cancer cells PC3 as well as on autophagy in these cancer cells. Induction of autophagy is a well-characterized phenomenon in prostate cancer, frequently associated with cancer cell survival and resistance to therapy $[9,10]$. Therefore, novel compounds that effectively inhibit prosurvival autophagy are of high interest [10,11]. p62 (or SQSTM) is a cargo protein that targets and binds other proteins to deliver them to autophagosomes for selective autophagy. During autophagy autophagosomes fuse with lysosomes and intra-autophagosomal components are degraded by lysosomal hydrolases. Therefore, an increased level of p62 has previously been associated with inhibition of autophagy flux. In our experiments MTT analysis revealed all compounds to be non-cytotoxic up to $100 \mu \mathrm{M}$ (data not shown). Consequently, we investigated the effect of the zosteropenillines on the expression of autophagy-related cargo protein p62. Western blotting analysis revealed a slight increase in p62 levels in PC3 cells treated with all the investigated substances (Figure 9), suggesting the drug-induced inhibition of autophagy. The effect on p62 expression was similar to the effect of Bafilomycin A1 (Baf)—a well-established autophagy inhibitor. These results suggest that the investigated compounds are able to inhibit autophagy at non-cytotoxic concentrations and may sensitize human cancer cells to cytotoxic anticancer drugs.

A

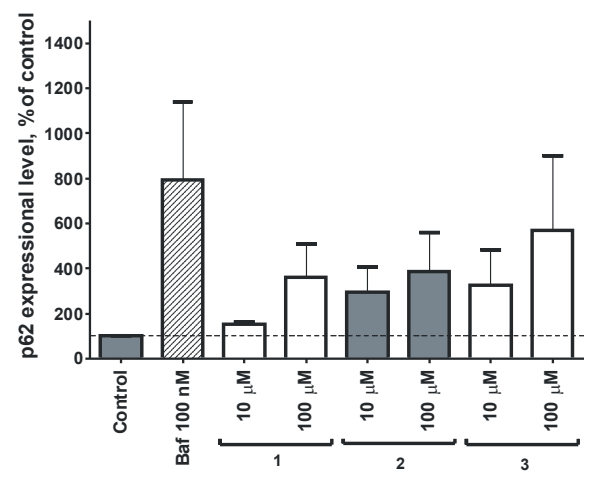

B

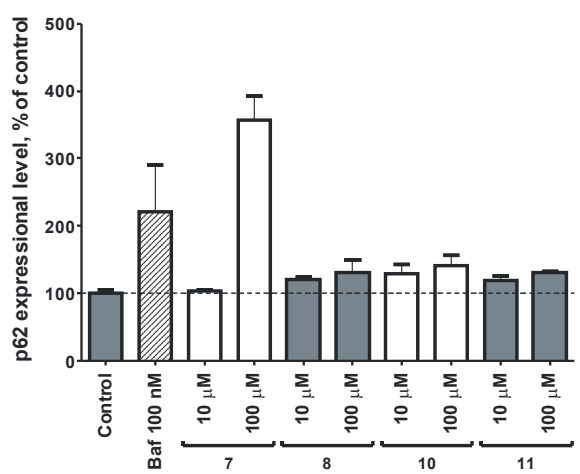

Figure 9. The effect on p62 expression. The expression of p62 in PC3 cells treated with the compounds 1-3 (A) and 7, 8, 10, 11 (B). Cells were treated for $48 \mathrm{~h}$, then proteins were extracted and both p62 and $\alpha$-tubulin levels were detected by Western blotting. The signals' intensity was quantified with Quantity One. Cells treated with the autophagy inhibitors bafilomycin A1 (Baf, $100 \mathrm{nM}$ ) were used as a positive control. The values are presented as mean \pm SEM. 


\section{Materials and Methods}

\subsection{General Experimental Procedures}

Optical rotations were measured on a Perkin-Elmer 343 polarimeter (Perkin Elmer, Waltham, MA, USA) in MeOH. UV spectra were recorded on a Specord UV VIS spectrometer (Carl Zeiss, Jena, Germany) in $\mathrm{MeOH}$ and in $n$-hexane. IR spectra were determined on a Specord M 82 (Carl Zeiss) in $\mathrm{CHCl}_{3}$. ECD spectra were measured with a Chirascan-Plus CD Spectrometer (Leatherhead, UK) in $\mathrm{MeOH}$ in $n$-hexane. X-ray crystallographic analysis was carried out on a Bruker Kappa APEX2 diffractometer with graphic-monochromated $\mathrm{Mo} \mathrm{K}_{\alpha}$ radiation. ${ }^{1} \mathrm{H}$ and ${ }^{13} \mathrm{C} \mathrm{NMR}$ spectra were recorded in $\mathrm{CDCl}_{3}$ and in DMSO- $d_{6}$ on a Bruker Avance-500 (Bruker BioSpin GmbH, Rheinstetten, Germany) and Avance III-700 (Bruker BioSpin GmbH, Rheinstetten, Germany) spectrometers operating at $500.13 \mathrm{MHz}$ and $125.77 \mathrm{MHz}$ and 700.13 and $176.04 \mathrm{MHz}$, respectively, using TMS as an internal standard. HRESIMS spectra were obtained on an Agilent 6510 Q-TOF LC mass spectrometer (Agilent Technologies, Santa Clara, CA, USA). Low-pressure liquid column chromatography was performed using Si gel L (50/100 $\mu \mathrm{m}$, Sorbpolimer, Imid, Krasnodar, Russia). Plates $(4.5 \times 6.0 \mathrm{~cm})$ pre-coated with Si gel (5-17 $\mu \mathrm{m}$, Sorbfil, Imid, Krasnodar, Russia) were used for thin layer chromatography. Preparative HPLC was carried out on a Shimadzu LC-20 (Shimadzu, USA Manufacturing, Canby, OR, USA) and Agilent 1100 (Agilent Technologies, Ratingen, Germany) chromatographs using an YMC ODS-AM (YMC Co, Ishikawa, Japan) $(5 \mu \mathrm{m}, 10 \times 250 \mathrm{~mm})$, YMC Si (YMC Co, Ishikawa, Japan) $(5 \mu \mathrm{m}$, $10 \times 250 \mathrm{~mm}$ ), Supelco Discovery C-18 (Supelco Analytical, Bellefonte, PA, USA) $(5 \mu \mathrm{m}, 4.6 \times 250 \mathrm{~mm})$, Ultrasphere Si (Beckman Coulter Inc., Brea CA, USA) $(5 \mu \mathrm{m}, 4.6 \times 250 \mathrm{~mm})$ and Kromasil 3-CelluCoat (Kromasil, Bohus, Sweden) $(4.6 \times 150 \mathrm{~mm})$ columns and Shimadzu RID-20A (Shimadzu Corporation, Kyoto, Japan) and Agilent 1100 (Agilent Technologies, Ratingen, Germany) refractometers.

\subsection{Fungal Strain}

The strain of the fungus Penicillium thomii KMM 4674 was isolated from superficial mycobiota of the rhizome sea-grass Zostera marina (Sea of Japan) and was identified on the basis of morphological evaluation.

\subsection{Cultivation of P. thomii}

The fungus was grown stationary at $22{ }^{\circ} \mathrm{C}$ for 21 days in 20 Erlenmeyer flasks (500 mL), each containing $20 \mathrm{~g}$ of rice, $20 \mathrm{mg}$ of yeast extract, $10 \mathrm{mg}$ of $\mathrm{KH}_{2} \mathrm{PO}_{4}$, and $40 \mathrm{~mL}$ of natural sea water (Marine Experimental Station of G.B. Elyakov Pacific Institute of Bioorganic Chemistry, Troitsa (Trinity) Bay, Sea of Japan) by Dr. Natalya Kirichuk.

\subsection{Extraction and Isolation}

At the end of the incubation period, the mycelia and medium were homogenized and extracted with EtOAc $(1 \mathrm{~L})$. The obtained extract was concentrated to dryness. The residue $(2.46 \mathrm{~g})$ was dissolved in $\mathrm{H}_{2} \mathrm{O}$-EtOH (4:1) $(100 \mathrm{~mL})$ and was extracted with $n$-hexane $(0.2 \mathrm{~L} \times 3)$ and EtOAc $(0.2 \mathrm{~L} \times 3)$. After evaporation of the EtOAc layer, the residual material (2.26 g) was passed over a silica column $(3 \times 14 \mathrm{~cm})$, which was eluted first with $n$-hexane $(200 \mathrm{~mL})$ followed by a step gradient from $5 \%$ to $50 \%$ EtOAc in $n$-hexane (total volume: $5 \mathrm{~L}$ ). Fractions of $250 \mathrm{~mL}$ were collected and combined on the basis of TLC (Si gel, toluene-isopropanol 6:1 and 3:1, v/v).

The $n$-hexane-EtOAc (75:25) eluate $(146 \mathrm{mg})$ was purified on an YMC ODS-AM column eluting with $\mathrm{MeOH}-\mathrm{H}_{2} \mathrm{O}(80: 20)$ to yield fractions A $(15.4 \mathrm{mg}), \mathrm{B}(10 \mathrm{mg}), \mathrm{C}(2.3 \mathrm{mg}), \mathrm{D}(3.3 \mathrm{mg})$, and individual compound $7(8.4 \mathrm{mg})$. Fraction A was purified on a Supelco C-18 eluting with $\mathrm{CH}_{3} \mathrm{CN}-\mathrm{H}_{2} \mathrm{O}$ (25:75) to yield 3 (2.3 mg). Fraction B was purified on a Kromasil 3-CelluCoat column eluting with $\mathrm{CH}_{3} \mathrm{CN}-\mathrm{H}_{2} \mathrm{O}(25: 75)$ to yield $4(3.0 \mathrm{mg})$. Fraction $\mathrm{C}$ was purified on an Ultrasphere Si column eluting with EtOAc-n-hexane-EtOH (50:50:5) to yield 9 (1.8 mg). Fraction D was purified on an Ultrasphere Si eluting with EtOAc-n-hexane-EtOH (100:100:5) to yield 5 (0.5 mg). The $n$-hexane-EtOAc (65:35) 
eluate (283 mg) was purified on a YMC ODS-AM column eluting with $\mathrm{MeOH}-\mathrm{H}_{2} \mathrm{O}$ (65:35) to yield 1 (11 mg), $\mathbf{6}$ (3.0 mg), 8 (6.1 mg), 10 (34.6 mg), $\mathbf{1 1}(4.6 \mathrm{mg})$ and $\mathbf{1 3}$ (100 mg). The $n$-hexane-EtOAc (60:40) eluate (200 mg) was purified on a YMC ODS-AM column eluting with $\mathrm{MeOH}-\mathrm{H}_{2} \mathrm{O}$ (65:35) to yield 2 (83 mg) and on a Supelco C-18 eluting with $\mathrm{CH}_{3} \mathrm{CN}-\mathrm{H}_{2} \mathrm{O}$ (80:20) to yield 12 (1.6 mg).

\subsection{Spectral Data}

Zosteropenilline A (1): colorless crystals; $[\alpha]_{\mathrm{D}}^{20}-125.0$ (c 0.1, MeOH); UV (n-hexane) low intensity band; CD (c 0.05, n-hexane), $\lambda_{\max }(\Delta \varepsilon) 202(-6.31), 300(-0.77), 310(-0.73), 321(-0.40) \mathrm{nm}$; IR $\left(\mathrm{CHCl}_{3}\right) v_{\max } 3462,2958,2928,1703,1648,1601,1444,1397,1120,1034 \mathrm{~cm}^{-1} ;{ }^{1} \mathrm{H}$ and ${ }^{13} \mathrm{C}$ NMR data, see Tables 1 and 2, Supplementary Figures S1-S8; HRESIMS [M $+\mathrm{Na}]^{+} m / z 273.1461$ (calcd. for $\mathrm{C}_{15} \mathrm{H}_{22} \mathrm{O}_{3} \mathrm{Na}$ 273.1461), [M+ H] ${ }^{+} m / z 251.1636$ (calcd. for $\mathrm{C}_{15} \mathrm{H}_{23} \mathrm{O}_{3}$ 251.1642).

Zosteropenilline $B(2)$ : colorless crystals; $[\alpha]_{\mathrm{D}}^{20}-161.6$ (c 0.12, MeOH); UV (MeOH low intensity band; $\mathrm{CD}(c 0.07, \mathrm{MeOH}), \lambda \max (\Delta \varepsilon) 201(-1.55), 291(-0.23), 332(+0.03), 365(-0.03) \mathrm{nm}$; IR $\left(\mathrm{CHCl}_{3}\right) v_{\max }$ 3460, 2957, 2919, 1701, 1602, 1455, 1385, 1108, $1055 \mathrm{~cm}^{-1} ;{ }^{1} \mathrm{H}$ and ${ }^{13} \mathrm{C}$ NMR data, see Tables 1 and 2, Supplementary Figures S11-S19; HRESIMS [M + Na] ${ }^{+} m / z 273.1474$ (calcd. for $\mathrm{C}_{15} \mathrm{H}_{22} \mathrm{O}_{3} \mathrm{Na}$ 273.1461), $[\mathrm{M}-\mathrm{H}]^{-} m / z 249.1496$ (calcd. for $\mathrm{C}_{15} \mathrm{H}_{21} \mathrm{O}_{3}$ 249.1496).

Zosteropenilline C (3): white solid; $[\alpha]_{\mathrm{D}}^{20}-170.0$ (c 0.1, MeOH); UV (MeOH) low intensity band; $\mathrm{CD}$ (c 0.07, MeOH), $\lambda_{\max }(\Delta \varepsilon) 204(-9.86), 297(-1.63) \mathrm{nm}$; IR $\left(\mathrm{CHCl}_{3}\right) v_{\max }$ 3604, 2973, 2927, 1705, 1602, 1453, 1375, 1140, $1044 \mathrm{~cm}^{-1} ;{ }^{1} \mathrm{H}$ and ${ }^{13} \mathrm{C}$ NMR data, see Tables 1 and 2, Supplementary Figures S20-S27; HRESIMS [M + Na] $]^{+} m / z 273.1463$ (calcd. for $\mathrm{C}_{15} \mathrm{H}_{22} \mathrm{O}_{3} \mathrm{Na} 273.1461$ ), [M - H] $]^{-} \mathrm{m} / z 249.1499$ (calcd. for $\mathrm{C}_{15} \mathrm{H}_{21} \mathrm{O}_{3}$ 249.1496).

Zosteropenilline D (4): amorphous; $[\alpha]_{\mathrm{D}}^{20}-56.0($ c 0.06, MeOH); $\mathrm{UV}(\mathrm{MeOH})$ low intensity band; $\mathrm{CD}$ (c 0.06, MeOH), $\lambda_{\max }(\Delta \varepsilon) 204(-4.01), 296(-0.96) \mathrm{nm}$; IR $\left(\mathrm{CHCl}_{3}\right) v_{\max } 2956,2929,1706,1602,1456$, 1376, 1121, $1069 \mathrm{~cm}^{-1} ;{ }^{1} \mathrm{H}$ and ${ }^{13} \mathrm{C}$ NMR data, see Tables 1 and 2, Supplementary Figures S28-S35; HRESIMS [M + Na] ${ }^{+} m / z 257.1510$ (calcd. for $\mathrm{C}_{15} \mathrm{H}_{22} \mathrm{O}_{2} \mathrm{Na} 257.1512$ ).

Zosteropenilline $E$ (5): amorphous; $[\alpha]_{\mathrm{D}}^{20}-16.0(c 0.05, \mathrm{MeOH}) ; \mathrm{UV}(\mathrm{MeOH})$ low intensity band; $\mathrm{CD}$ $(c 0.05, \mathrm{MeOH}), \lambda_{\max }(\Delta \varepsilon) 206(-0.27), 293(-0.21), 299(-0.22), 305(-0.19), 339(-0.03) ;{ }^{1} \mathrm{H}$ and ${ }^{13} \mathrm{C}$ NMR data, see Tables 1 and 2, Supplementary Figures S36-S42; HRESIMS [M - H] $]^{-} m / z 283.1538$ (calcd. for $\mathrm{C}_{15} \mathrm{H}_{23} \mathrm{O}_{5}$ 283.1551).

Zosteropenilline $F(6)$ : white solid; $[\alpha]_{\mathrm{D}}^{20}+9.1(c$ 0.11, $\mathrm{MeOH})$; UV (MeOH) low intensity band; $\mathrm{CD}$ $(c 0.07, \mathrm{MeOH}), \lambda_{\max }(\Delta \varepsilon) 194(+0.70), 204(-1.14), 230(-0.12), 293(+0.08), 319(-0.02) \mathrm{nm} ; \mathrm{IR}\left(\mathrm{CHCl}_{3}\right)$ $v_{\max } 3621,2976,2928,1702,1602,1450,1390,1046 \mathrm{~cm}^{-1} ;{ }^{1} \mathrm{H}$ and ${ }^{13} \mathrm{C}$ NMR data, see Tables 1 and 2, Supplementary Figures S43-S50; HRESIMS [M + Na] ${ }^{+} m / z 291.1579$ (calcd. for $\mathrm{C}_{15} \mathrm{H}_{24} \mathrm{O}_{4} \mathrm{Na}$ 291.1567), $[2 \mathrm{M}+\mathrm{Na}]^{+} m / z 559.3242$ (calcd. for $2 \mathrm{C}_{15} \mathrm{H}_{24} \mathrm{O}_{4} \mathrm{Na} 559.3241$ ).

Zosteropenilline $G$ (7): white solid; $[\alpha]_{\mathrm{D}}^{20}-15.3($ c $0.034, \mathrm{MeOH}) ; \mathrm{UV}(\mathrm{MeOH}) \lambda_{\max }(\log \varepsilon)$ low intensity band; $\mathrm{CD}(c 0.05, \mathrm{MeOH}), \lambda_{\max }(\Delta \varepsilon) 199(-1.85), 218(-1.07), 244(+0.11), 287(+0.57) \mathrm{nm}$; IR $\left(\mathrm{CHCl}_{3}\right)$ $v_{\max } 3623,3459,2884,1704,1670,1602,1455,1391,1056 \mathrm{~cm}^{-1} ;{ }^{1} \mathrm{H}$ and ${ }^{13} \mathrm{C}$ NMR data, see Tables 3 and 4 , Supplementary Figures S69-S77; HRESIMS [M + Na] ${ }^{+} m / z$ 275.1621 (calcd. for $\mathrm{C}_{15} \mathrm{H}_{24} \mathrm{O}_{3} \mathrm{Na}$ 275.1618), $[\mathrm{M}-\mathrm{H}]^{-} m / z 251.1646$ (calcd. for $\mathrm{C}_{15} \mathrm{H}_{23} \mathrm{O}_{3}$ 251.1653).

Zosteropenilline $H(8)$ : amorphous; $[\alpha]_{\mathrm{D}}^{20}+83.4(c 0.11, \mathrm{MeOH})$; $\mathrm{UV}(\mathrm{MeOH})$ low intensity band; $\mathrm{CD}$ (c 0.06, MeOH), $\lambda_{\max }(\Delta \varepsilon) 209(+3.62), 295(+1.98) \mathrm{nm}$; IR $\left(\mathrm{CHCl}_{3}\right) v_{\max }$ 3617, 3489, 2959, 2929, 1703, $1602,1456,1383,1055 \mathrm{~cm}^{-1} ;{ }^{1} \mathrm{H}$ and ${ }^{13} \mathrm{C}$ NMR data, see Tables 3 and 4, Supplementary Figures S78-S85; HRESIMS [M + Na] ${ }^{+} m / z 291.1571$ (calcd. for $\mathrm{C}_{15} \mathrm{H}_{24} \mathrm{O}_{4} \mathrm{Na} 291.1567$ ), $[2 \mathrm{M}+\mathrm{Na}]^{+} m / z 559.3236$ (calcd. for $2 \mathrm{C}_{15} \mathrm{H}_{24} \mathrm{O}_{4} \mathrm{Na} 559.3241$ ). 
Zosteropenilline I (9): white solid; $[\alpha]_{\mathrm{D}}^{20}+80.0($ c 0.07, $\mathrm{MeOH})$; $\mathrm{UV}(\mathrm{MeOH})$ low intensity band; $\mathrm{CD}$ $(c 0.04, \mathrm{MeOH}), \lambda_{\max }(\Delta \varepsilon) 204(-6.61), 247(-1.13) \mathrm{nm} ;{ }^{1} \mathrm{H}$ and ${ }^{13} \mathrm{C}$ NMR data, see Tables 3 and 4 , Supplementary Figures S86-S93; HRESIMS [M + Na] ${ }^{+} m / z 273.1462$ (calcd. for $\mathrm{C}_{15} \mathrm{H}_{22} \mathrm{O}_{3} \mathrm{Na}$ 273.1461), $[2 \mathrm{M}+\mathrm{Na}]^{+} m / z 523.3029$ (calcd. for $2 \mathrm{C}_{15} \mathrm{H}_{22} \mathrm{O}_{3} \mathrm{Na} 523.3030$ ).

Zosteropenilline J (10): colorless crystals; $[\alpha]_{\mathrm{D}}^{20}-52.9($ c 0.71, $\mathrm{MeOH}) ; \mathrm{UV}(\mathrm{MeOH})$ low intensity band; $\mathrm{CD}(c 0.06, \mathrm{MeOH}), \lambda_{\max }(\Delta \varepsilon) 196$ (-3.81), $213(+0.35), 238(+0.05), 295(-2.15) \mathrm{nm}$; IR $\left(\mathrm{CHCl}_{3}\right) v_{\max }$ 3605, 3497, 2959, 2929, 1702, 1602, 1456, 1383, $1061 \mathrm{~cm}^{-1} ;{ }^{1} \mathrm{H}$ and ${ }^{13} \mathrm{C}$ NMR data, see Tables 3 and 4 , Supplementary Figures S94-S101; HRESIMS [M + Na] ${ }^{+} \mathrm{m} / z 291.1573$ (calcd. for $\mathrm{C}_{15} \mathrm{H}_{24} \mathrm{O}_{4} \mathrm{Na}$ 291.1567), $[2 \mathrm{M}+\mathrm{Na}]^{+} m / z 559.3236$ (calcd. for $2 \mathrm{C}_{15} \mathrm{H}_{24} \mathrm{O}_{4} \mathrm{Na} 559.3241$ ).

Zosteropenilline K (11): amorphous; $[\alpha]_{\mathrm{D}}^{20}+11.1($ c 0.09, $\mathrm{MeOH}) ; \mathrm{UV}(\mathrm{MeOH}) \lambda_{\max }(\log \varepsilon) 242(3.46) \mathrm{nm}$; $\mathrm{CD}(c 0.06, \mathrm{MeOH}), \lambda_{\max }(\Delta \varepsilon) 193(0.75), 219(-4.62), 244(+0.65), 258(-0.13), 279(0.46), 294(0.41), 318$ (0.35) nm; IR $\left(\mathrm{CHCl}_{3}\right) v_{\max } 3617,3464,2958,2927,1702,1671,1653,1604,1456,1390,1059 \mathrm{~cm}^{-1} ;{ }^{1} \mathrm{H}$ and ${ }^{13} \mathrm{C}$ NMR data, see Tables 3 and 4, Supplementary Figures S102-S109; HRESIMS $[\mathrm{M}+\mathrm{Na}]^{+} \mathrm{m} / z$ 305.1370 (calcd. for $\mathrm{C}_{15} \mathrm{H}_{22} \mathrm{O}_{5} \mathrm{Na} 305.1359$ ).

Zosteropenilline $L$ (12): amorphous; $[\alpha]_{\mathrm{D}}^{20}-54($ c 0.05, $\mathrm{MeOH})$; UV (MeOH) low intensity band; $\mathrm{CD}$ (c 0.05, MeOH), $\lambda_{\max }(\Delta \varepsilon) 196(-1.29), 210(+0.14), 298(-1.12), 349(+0.04) \mathrm{nm} ;{ }^{1} \mathrm{H}$ and ${ }^{13} \mathrm{C}$ NMR data, see Tables 3 and 4, Supplementary Figures S110-S117; HRESIMS [M + Na] $]^{+} m / z 307.1501$ (calcd. for $\mathrm{C}_{15} \mathrm{H}_{24} \mathrm{O}_{5} \mathrm{Na}$ 307.1516).

Pallidopenilline $A$ (13): colorless crystals; $[\alpha]_{\mathrm{D}}^{20}-21$. ( $\left.0.1, \mathrm{MeOH}\right) ; \mathrm{UV}(\mathrm{MeOH}) \lambda_{\max }(\log \varepsilon)$ low intensity band; $\mathrm{CD}(c 0.1, \mathrm{MeOH}), \lambda_{\max }(\Delta \varepsilon) 196(-9.89), 213(+1.14), 294(-1.78) \mathrm{nm} ;{ }^{1} \mathrm{H}$ and ${ }^{13} \mathrm{C}$ NMR data, Supplementary Figures S51-S65; HRESIMS [M + Na] ${ }^{+} m / z 291.1575$ (calcd. for $\mathrm{C}_{15} \mathrm{H}_{24} \mathrm{O}_{5} \mathrm{Na}$ 291.1567).

\subsection{Preparation of (S)-MTPA and (R)-MTPA Esters of $\mathbf{1}$}

To a solution of $\mathbf{1}(1.75 \mathrm{mg}$ ) in pyridine were added 4-dimethylaminopyridine (a few crystals) and (R)-MTPA-Cl $(1.2 \mu \mathrm{L})$ at room temperature, and the mixture was stirred for $1.5 \mathrm{~h}$. After evaporation of the solvent, the residue was purified by HPLC on an YMC Si $(5 \mu \mathrm{m}, 10 \times 250 \mathrm{~mm})$ column eluted with $n$-hexane-acetone (85:15) to afford the (S)-MTPA ester of $\mathbf{1}(\mathbf{1 a})$. The $(R)$-MTPA ester of $\mathbf{1}(\mathbf{1} \mathbf{b})$ was prepared similarly manner using (S)-MTPA-Cl. NMR data of $(R, S)$-MTPA esters of 1 (Figure S10). HRESIMS (1a) $m / z 489.1864[\mathrm{M}+\mathrm{Na}]^{+}$(calcd. for $\mathrm{C}_{25} \mathrm{H}_{29} \mathrm{~F}_{3} \mathrm{O}_{5} \mathrm{Na}, 489.1859$ ), $m / z 955.3830\left[2 \mathrm{M}+\mathrm{Na}^{+}\right.$ (calcd for $\mathrm{C}_{50} \mathrm{H}_{58} \mathrm{~F}_{6} \mathrm{O}_{10} \mathrm{Na}$, 955.3826); HRESIMS (1b) $\mathrm{m} / z 489.1858$ [M + Na] ${ }^{+}$(calcd. for $\mathrm{C}_{25} \mathrm{H}_{29} \mathrm{~F}_{3} \mathrm{O}_{5} \mathrm{Na}$, 489.1859), $m / z$ 955.3815 [2M + Na] ${ }^{+}$(calcd for $\mathrm{C}_{50} \mathrm{H}_{58} \mathrm{~F}_{6} \mathrm{O}_{10} \mathrm{Na}$, 955.3826).

\subsection{X-ray Crystal Data for $\mathbf{1}$}

Experimental intensity data for $\mathrm{C}_{15} \mathrm{H}_{22} \mathrm{O}_{3}$ were collected at $\mathrm{T}=296(2) \mathrm{K}\left(\alpha-\mathrm{C}_{15} \mathrm{H}_{22} \mathrm{O}_{3}\right)$ on a BRUKER Kappa APEX2 diffractometer with graphite monochromated Mo $\mathrm{K}_{\alpha}$ radiation $(\lambda=0.71073 \AA)$. Intensity data were corrected for absorption using the multi-scan method. The structures were solved using direct methods and refined by least-squares calculation in anisotropic approximation for non-hydrogen atoms. Hydrogen atoms were placed at idealized positions and refined using a riding model. Data collection, reduction, and refinement of the lattice parameters were performed using the Apex II software package [12]. All calculations were performed with SHELXL/PC program [13]. Selected bond lengths and hydrogen bonds are listed in the Supplementary Materials, Figure S8. Supplementary crystallographic data (accession numbers CCDC 1522593) can be obtained free of charge from the Cambridge Crystallographic Data Center via http://www.ccdc.cam.ac.uk/data request/cif (or from the Cambridge Crystallographic Data Centre, 12 Union Road, Cambridge, UK; fax: + 441223336033 or email: deposit@ccdc.cam.uk). 


\subsection{Quantum Chemical Modeling}

The conformational analyses of $\mathbf{1}$ in a hexane solvent and for $\mathbf{2}-\mathbf{4}$ in a $\mathrm{CH}_{3} \mathrm{OH}$ solvent were done using density functional theory (DFT) with the exchange-correlation functional PBE1PBE [14], the polarization continuum model (PCM) [15] and 6-311+G(d) split-valence basis set, implemented in the Gaussian 03 package of programs [16]. The molecular cavity was modeled according to unified force field $($ radii $=U F F)$. The statistical weights $\left(g_{i m}\right)$ of different conformations of $\mathbf{1}-\mathbf{4}$ were obtained according to Equation (1):

$$
g_{i m}=\frac{e^{-\Delta G_{i m} / R T}}{\sum_{i} e^{-\Delta G_{i m} / R T}}
$$

where the summation was done over all possible conformations of 1-4 and $\Delta G_{i m}=G_{i}-G_{m} ; G=E_{\mathrm{el}}+$ $G_{\mathrm{tr}, \mathrm{T}}+G_{\mathrm{rot}, \mathrm{T}}+G_{\mathrm{vib}, \mathrm{T}}$ is a sum of electronic, translational, rotational, and vibrational contributions to the Gibbs free energy, calculated at temperature $\mathrm{T}=298.15 \mathrm{~K}$; the subscript " $\mathrm{m}$ " denotes conformation, for which $G$ is minimal. The excitation energies and the rotatory strengths were calculated using time-dependent density functional theory (TDDFT). Theoretical ECD spectra $\left(\Delta \varepsilon_{\text {calc }}(\lambda)\right)$ were simulated as a superposition of Gauss-type functions, individual for each transition from electronic ground state to the $i$-th calculated excited electronic state $(1 \leq i \leq 50)$. The same value $\xi=0.20 \mathrm{eV}$ for the bandwidths at $1 / e$ peak heights was used. The total theoretical ECD spectra were obtained after statistical averaging:

$$
\varepsilon_{\text {calc }}(\lambda)=\sum_{i} g_{i} \cdot \Delta \varepsilon_{i, \text { calc }}(\lambda)
$$

The scaled theoretical and experimental ECD spectra were obtained according to Equation (3):

$$
\varepsilon_{\text {scaled }}(\lambda)=\frac{\Delta \varepsilon(\lambda)}{\left|\Delta \varepsilon\left(\lambda_{\text {peak }}\right)\right|}
$$

where the denominator $\left|\Delta \varepsilon\left(\lambda_{\text {peak }}\right)\right|$ is a modulo of the peak value for the chosen characteristic band in the corresponding ECD spectrum.

\subsection{Measurement of Nitric Oxide Content}

RAW 264.7 murine macrophages were plated into 96-well microplates and incubated at $37^{\circ} \mathrm{C}$ with $5 \% \mathrm{CO}_{2}$ for $2 \mathrm{~h}$. After adhesion, cells were incubated with tested compounds $(10.0 \mu \mathrm{M})$ for $24 \mathrm{~h}$. For endogenously generated NO detection studies, the cells were coincubated with $10 \mu \mathrm{M}$ of FA-OMe fluorescent probe for $8 \mathrm{~h}$ [17]. Prior to fluorescence registration, the cells were washed three times with PBS and then bathed in $200 \mu \mathrm{L} /$ well of PBS. Green fluorescence of cells was registered at $\lambda_{\mathrm{ex}}=460 \mathrm{~nm}$ and $\lambda_{\mathrm{em}}=524 \mathrm{~nm}$. In each experiment LPS from E. coli serotype 055:B5 $(1.0 \mu \mathrm{g} / \mathrm{mL}$, Sigma-Aldrich, St. Louis, MO, USA) were used as a positive control. Fluorescent intensity was measured using plate reader PHERAstar FS (BMG Labtech GmbH, Ortenberg, Germany).

\subsection{Statistical Analysis}

All assays were performed at least in triplicate. The results are expressed as the mean \pm standard error (SD). A Student's $t$-test was used to evaluate the data with the significance level of $p<0.05$. The means and standard errors for each treatment were calculated and plotted using SigmaPlot 3.02 software (Jandel Scientific, San Rafael, CA, USA).

\subsection{Cell Lines and Culture Conditions}

The human prostate cancer cells line PC-3 was purchased from ATCC. Cells were cultured according to the manufacturer's instructions in 10\% FBS/RPMI media (Invitrogen, Paisley, UK) containing penicillin/streptomycin (Invitrogen). Cells were continuously kept in culture for a maximum of three months, and were routinely inspected microscopically for stable phenotype and 
regularly checked for contamination with mycoplasma. Cell line authentication was recently performed by DSMZ (Braunschweig, Germany) using highly polymorphic short tandem repeat loci [18].

\subsection{In Vitro MTT-Based Drug Sensitivity Assay}

The in vitro cytotoxicity of individual substances was evaluated using the MTT (3-(4,5-dimethylthiazol-2-yl)-2,5-diphenyltetrazolium bromide) assay, which was performed as previously described [19].

\subsection{Western Blotting}

Western blotting was performed as described before [19]. For detection of the proteins following primary and secondary antibody were used: anti-SQSTM/p62 (\#5114, 1:1000, Cell Signaling Technology, Danvers, MA, USA), anti- $\alpha$-tubulin (T5168, 1:10,000, Sigma-Aldrich, St. Louis, MO, USA), anti-mouse IgG-HRP (NXA931, 1:10,000, GE Healthcare, Little Chalfont, UK), anti-rabbit IgG-HRP (Cell Signaling Technology, Danvers, MA, USA, \#7074, 1:5000). Signals were detected using the ECL chemiluminescence system (Thermo Scientific, Rockford, IL, USA) according to the manufacturer's protocol. Relative optical density of the signal intensity of the bands was quantified with Quantity One 4.6 software (Bio-Rad, Hercules, CA, USA) and normalized first, against corresponding signal of $\alpha$-tubulin (loading control), and second, against the signal of control sample. Mean values of two independent experiments \pm SEM are presented. SEM values were calculated using GraphPad Prism software v. 5.01 (GraphPad Prism software Inc., La Jolla, CA, USA).

\section{Conclusions}

Zosteropenillines A-L (1-12) belong to the series of lovastatin-related polyketides that are formed by an enzymatic intramolecular Diels-Alder cycloaddition of a linear hexaketide precursor [20-22]. Polyketides containing "decalin" moiety exhibit diverse biological properties such as anticancer, antimicrobial, neurotrophic, and growth-stimulating activity [23-27]. Twelve new polyketides, named zosteropenillines A-L (1-12), have been isolated from the extract of the marine-derived fungus Penicillium thomii. The absolute configuration zosteropenilline A (1) was determined by a combination of the modified Mosher's method, X-ray analysis, and NOESY data. Absolute configurations of zosteropenillines B-D (2-4) were determined by time-dependent density functional theory (TD-DFT) calculations of ECD spectra. Zosteropenillines B, G, and I at a non-toxic concentration of $10.0 \mu \mathrm{M}$ induced a moderate downregulation of NO production in macrophages stimulated with LPS.

Supplementary Materials: ${ }^{1} \mathrm{H},{ }^{13} \mathrm{C}, \mathrm{DEPT}, \mathrm{COSY}-45, \mathrm{HSQC}, \mathrm{HMBC}$ and NOESY spectra of all compounds are available online at www.mdpi.com/1660-3397/15/2/46/s1.

Acknowledgments: The study was supported by grant No. 14-14-00030 from the Russian Science Foundation.

Author Contributions: Shamil Sh. Afiyatullov supervised research and wrote the manuscript; Elena V. Leshchenko designed the project, isolated compounds and elucidated their structure, discussed results, and wrote the manuscript; Alexandr S. Antonov and Maria P. Sobolevskaya isolated and recrystallized compounds; Anatoly A. Udovenko performed X-ray experiments; Mikhail V. Pivkin cultivated the fungus; Roman S. Popov performed MS experiments; Vladimir A. Denisenko performed NMR experiments; Dmitrii V. Berdyshev calculated ECD spectra, discussed the results, and helped to write the manuscript; Evgeny A. Pislyagin evaluated inhibitory effects on NO production; Gunhild von Amsberg designed bioassays, raised financial support for biological experiments with human cells, and discussed the results; Sergey A. Dyshlovoy performed and designed bioassays with human cells, discussed the results, and helped to write the manuscript. The authors are grateful to the Far Eastern Center of Structural Research for performing the X-ray investigation.

Conflicts of Interest: The authors declare no conflict of interest.

\section{References}

1. Blunt, J.W.; Copp, B.R.; Keyzers, R.A.; Munro, M.H.G.; Prinsep, M.R. Marine natural products. Nat. Prod. Rep. 2016, 33, 382-431. [CrossRef] [PubMed] 
2. Rateb, M.E.; Ebel, R. Secondary metabolites of fungi from marine habitats. Nat. Prod. Rep. 2011, 28, $290-344$. [CrossRef] [PubMed]

3. Liming, J.; Chunshan, Q.; Xiyan, H.; Shengdi, F. Potential pharmacological resources: Natural bioactive compounds from marine-derived fungi. Mar. Drugs 2016, 14, 76.

4. Zhuravleva, O.I.; Sobolevskaya, M.P.; Leshchenko, E.V.; Kirichuk, N.N.; Denisenko, V.A.; Dmitrenok, P.S.; Dyshlovoy, S.A.; Zakharenko, A.M.; Kim, N.Y.; Afiyatullov, S.S. Meroterpenoids from the AlgA-Derived Fungi Penicillium thomii Maire and Penicillium lividum Westling. J. Nat. Prod. 2014, 77, 1390-1395. [CrossRef] [PubMed]

5. Zhuravleva, O.I.; Sobolevskaya, M.P.; Afiyatullov, S.S.; Kirichuk, N.N.; Denisenko, V.A.; Dmitrenok, P.S.; Yurchenko, E.A.; Dyshlovoy, S.A. Sargassopenillines A-G, 6,6-Spiroketals from the AlgA-Derived Fungi Penicillium thomii and Penicillium lividum. Mar. Drugs 2014, 12, 5930-5943. [CrossRef] [PubMed]

6. Afiyatullov, S.S.; Leshchenko, E.V.; Sobolevskaya, M.P.; Denisenko, V.A.; Kirichuk, N.N.; Khudyakova, Y.V.; Hoai, T.P.T.; Dmitrenok, P.S.; Menchinskaya, E.S.; Pislyagin, E.A.; et al. New eudesmane sesquiterpenes from the marine-derived fungus Penicillium thomii. Phytochem. Lett. 2015, 14, 209-214. [CrossRef]

7. Sobolevskaya, M.P.; Leshchenko, E.V.; Hoai, T.P.T.; Denisenko, V.A.; Dyshlovoy, S.A.; Kirichuk, N.N.; Khudyakova, Y.V.; Kim, N.Y.; Berdyshev, D.V.; Pislyagin, E.A.; et al. Pallidopenillines: Polyketides from the algA-derived fungus Penicillium thomii Maire KMM 4675. J. Nat. Prod. 2016, 79, 3031-3038. [CrossRef] [PubMed]

8. Kendall, R.A.; Dunning, T.H.; Harrison, R.J. Electron affinities of the first-row atoms revisited. Systematic basis sets and wave functions. J. Chem. Phys. 1992, 96, 6796-6806. [CrossRef]

9. Kung, H.J.; Changou, C.; Nguyen, H.G.; Yang, J.C.; Evans, C.P.; Bold, R.J.; Chuang, F. Autophagy and Prostate Cancer Therapeutics. In Prostate Cancer; Tindal, D.J., Ed.; Springer: New York, NY, USA, 2013; Volume 16, pp. 497-518.

10. Farrow, J.M.; Yang, J.C.; Evans, C.P. Autophagy as a modulator and target in prostate cancer. Nat. Rev. Urol. 2014, 11, 508-516. [CrossRef] [PubMed]

11. Sui, X.; Chen, R.; Wang, Z.; Huang, Z.; Kong, N.; Zhang, M.; Han, W.; Lou, F.; Yang, J.; Zhang, Q.; et al. Autophagy and chemotherapy resistance: A promising therapeutic target for cancer treatment. Cell Death Dis. 2013, 4, e838. [CrossRef] [PubMed]

12. APEX2, Bruker AXS Inc.: Madison, WI, USA, 2010.

13. Sheldrick, G.M. SHELXT-Integrated space-group and crystalstructure determination. Acta Crystallogr. Sect. A Found. Adv. 2015, A71, 3-8. [CrossRef] [PubMed]

14. Adamo, C.; Barone, V. Toward reliable density functional methods without adjustable parameters: The PBE0 model. J. Chem. Phys. 1999, 110, 6158-6170. [CrossRef]

15. Miertus, S.; Scrocco, E.; Tomasi, J. Electrostatic interaction of a solute with a continuum-A direct utilation of abinitio molecular potentials for the prevision of solvent effects. Chem. Phys. 1981, 55, 117-129. [CrossRef]

16. Frisch, M.J.; Trucks, G.W.; Schlegel, H.B.; Scuseria, G.E.; Robb, M.A.; Cheeseman, J.R.; Montgomery, J.A., Jr.; Vreven, T.; Kudin, K.N.; Burant, J.C.; et al. Gaussian 03, Revision D.01; Gaussian, Inc.: Wallingford, CT, USA, 2004.

17. Shiue, T.W.; Chen, Y.H.; Wu, C.M.; Singh, G.; Chen, H.-Y.; Hung, C.-H.; Liaw, W.F.; Wang, Y.M. Nitric Oxide Turn-on Fluorescent Probe Based on Deamination of Aromatic Primary Monoamines. Inorg. Chem. 2012, 51, 5400-5408. [CrossRef] [PubMed]

18. Dyshlovoy, S.A.; Menchinskaya, E.S.; Venz, S.; Rast, S.; Amann, K.; Hauschild, J.; Otte, K.; Kalinin, V.I.; Silchenko, A.S.; Avilov, S.A.; et al. The marine triterpene glycoside frondoside A exhibits activity in vitro and in vivo in prostate cancer. Int. J. Cancer 2016, 138, 2450-2465. [CrossRef] [PubMed]

19. Dyshlovoy, S.A.; Venz, S.; Shubina, L.K.; Fedorov, S.N.; Walther, R.; Jacobsen, C.; Stonik, V.A.; Bokemeyer, C.; Balabanov, S.; Honecker, F. Activity of aaptamine and two derivatives, demethyloxyaaptamine and isoaaptamine, in cisplatin-resistant germ cell cancer. J. Proteom. 2014, 96, 223-239. [CrossRef] [PubMed]

20. Li, G.; Kusari, S.; Spireller, M. Natural products containing 'decalin' motif in microorganisms. Nat. Prod. Rep. 2014, 31, 1175-1201. [CrossRef] [PubMed]

21. Stocking, E.M.; Williams, R.M. Chemistry and biology of biosynthetic Diels-Alder reactions. Angew. Chem. Int. Ed. 2003, 42, 3078-3115. [CrossRef] [PubMed]

22. Lin, T.; Lin, X.; Lu, Z.; Huang, W.; Huang, Y.; Shen, Y. Secondary metabolites of Phomopsis sp. XZ-26, an endophytic fungus from Camptotheca acuminate. Eur. J. Chem. 2009, 18, 2975-2982. 
23. Anisimov, M.M.; Chaikina, E.L.; Afiyatullov, S.S.; Zhuravleva, O.I.; Klykov, A.G.; Kraskovskaja, N.A.; Aminin, D.L. Decumbenones A-C from marine fungus Aspergillus sulphureus as stimulators of the initial stages of development of agricultural plants. Agric. Sci. 2012, 3, 1019-1022.

24. Jadulco, R.C.; Koch, M.; Kakule, T.B.; Schmidt, E.W.; Orendt, A.; He, H.; Janso, J.E.; Carter, G.T.; Larson, E.C.; Pond, C.; et al. Isolation of pyrrolocins A-C: Cis- and trans-decalin tetramic acid antibiotics from an endophytic fungal-derived pathway. J. Nat. Prod. 2014, 77, 2537-2544. [CrossRef] [PubMed]

25. Tsukamoto, S.; Miura, S.; Yamashita, Y.; Ohta, T. Aspermytin A: A new neurotrophic polyketide isolated from a marine-derived fungus of the genus Aspergillus. Bioorg. Med. Chem. Lett. 2004, 14, 417-420. [CrossRef] [PubMed]

26. Zhuravleva, O.I.; Afiyatullov, S.S.; Vishchuk, O.S.; Denisenko, V.A.; Slinkina, N.N.; Smetanina, O.F. Decumbenone $\mathrm{C}$, a new cytotoxic decaline derivative from the marine fungus Aspergillus sulphureus KMM 4640. Arch. Pharm. Res. 2012, 35, 1757-1762. [CrossRef] [PubMed]

27. Guo, H.; Feng, T.; Li, Z.; Liu, J. Five new polyketides from the basidiomycete Craterellus odoratus. Nat. Prod. Bioprospect. 2012, 2, 170-173. [CrossRef]

(C) 2017 by the authors; licensee MDPI, Basel, Switzerland. This article is an open access article distributed under the terms and conditions of the Creative Commons Attribution (CC BY) license (http:/ / creativecommons.org/licenses/by/4.0/). 